\title{
TRANSNATIONAL LAW, DOMESTIC COURTS, AND GLOBAL GOVERNANCE
}

\author{
By Christopher A. Whytock
}

[DRAFT: March 15, 2007, Revised]

NOTE: This working paper, which will not be submitted for publication, has been replaced by two separate articles: (1) Domestic Courts and Global Governance, 84 Tulane LAW REviEw 67 (2009), which presents a substantially revised version of the conceptual and methodological argument; and (2) The Evolving Forum Shopping System, 96 CORNell LAW REviEW (forthcoming), which contains an empirical analysis of forum non conveniens decisionmaking. If citing, please cite these new versions. Please do not cite this older working paper without the author's permission.]

- Associate Professor, University of Utah S.J. Quinney College of Law; Ph.D. Candidate, Department of Political Science, Duke University. This paper was prepared for presentation at the 2007 annual meeting of the American Society of International Law, as part of the New Voices panel on Institutions and the Rule of Law. I thank the Society for inviting me to present my research, Scott Diamond for coordinating the panel, and Ambassador Richard Gardner for moderating. 


\title{
TRANSNATIONAL LAW, DOMESTIC COURTS, AND GLOBAL GOVERNANCE
}

\author{
By Christopher A. Whytock ${ }^{*}$
}

[DRAFT: March 15, 2007, Revised]

Domestic courts are global governors. In the United States federal courts alone, thousands of disputes arising out of transnational activity are heard each year. ${ }^{1}$ Substantively, the decisions of courts in these cases allocate resources among transnational actors.

Jurisdictionally, they allocate governance authority among states by determining whether a domestic or foreign court should adjudicate a dispute, whether domestic or foreign law should be applied to govern the underlying transnational activity, and whether the decisions of foreign courts in transnational disputes should be given domestic effect. Moreover, when domestic courts publish their transnational litigation decisions, they not only directly affect the litigants; they also provide information about how they are likely to decide similar cases in the future, information that can indirectly influence the strategic behavior of transnational actors beyond a particular dispute.

Yet the governance of transnational activity by domestic courts—which I refer to as "transnational judicial governance" ${ }^{2}$ - has received little scholarly attention, ${ }^{3}$ even though legal scholars and political scientists have long appreciated the role of domestic courts in the governance of domestic activity, ${ }^{4}$ and are increasingly interested in the role of international courts in the governance of both domestic and international activity. ${ }^{5}$ As a result, we have a very

\footnotetext{
${ }^{1}$ Between 1995 and 2005, an average of 3,285 cases per year based on diversity jurisdiction and involving at least one non-U.S. party were terminated in U.S. district courts, according to data obtained from the Federal Judicial Center. Diversity of citizenship is only one basis for U.S. federal court jurisdiction over transnational disputes. This figure therefore excludes transnational disputes that are brought in federal courts based on jurisdictional grounds other than diversity, such as federal question jurisdiction. It also excludes transnational suits that do not involve a non-U.S. party (but involve activity with connections to more than one state), that are brought in U.S. state courts, or that are brought in non-U.S. courts. Therefore, this figure only offers an estimate of the minimum number of transnational disputes in domestic courts each year.

${ }^{2}$ Christopher A. Whytock, Politics and the Rule of Law in Transnational Judicial Governance: The Case of Forum Non Conveniens (Feb. 2007) (unpublished manuscript, available at http://ssrn.com/abstract $=969033$ ) [hereinafter Whytock, Transnational Judicial Governance]; Christopher A. Whytock, Domestic Courts and Global Governance (Aug. 2006) (unpublished manuscript, available at http://ssrn.com/abstract=923907 [hereinafter Whytock, Domestic Courts and Global Governance].

${ }^{3}$ Cf. Samuel P. Baumgartner, “Is Transnational Litigation Different?” 25 U. Pa. J. Int'l Econ. L. 1297, 1302 (2004) (noting that the foundations of transnational litigation "have largely remained untouched by systematic scholarship").

${ }^{4}$ See, e.g., Robert Dahl, Decision-Making in a Democracy: The Role of the Supreme Court as National PolicyMaker, 6 J. of Pub. L. 279 (1957); Ran Hirschl, Towards Juristocracy: The Origins and Consequences of the New Constitutionalism (2004); Martin Shapiro, Courts: A Comparative and Political Analysis (1981); Alec Stone Sweet, Governing with Judges: Constitutional Politics in Europe (2000); and Neal C. Tate \& Torbjörn Vallinder, The Global Expansion of Judicial Power (1995).

${ }^{5}$ See, e.g., Karen Alter, Private Litigants and the New International Courts, 39 Comp. Pol. Stud. 22 (2006); Rachel A. Cichowski, Courts, Democracy, and Governance, 39 Comp. Pol. Stud. 3 (2006); Laurence R. Helfer \& AnneMarie Slaughter, Toward a Theory of Effective Supranational Adjudication, 107 Yale L.J. 273 (1997); Erik Voeten, Judicial Behavior on International Courts: The European Court of Human Rights (2006) (unpublished manuscript,
} 
limited understanding of how domestic courts behave as global governors, and why they govern the way they do.

In this paper, I propose a governance-oriented approach for analyzing transnational law aimed at improving our understanding of transnational judicial governance. In Part I, I clarify the concept of transnational judicial governance by exploring the global governance implications of judicial decisionmaking in transnational litigation, and I attempt to demonstrate the importance of transnational judicial governance as a distinct object of study. Part II describes the governance-oriented approach, including its focus on transnational law in action and on the broad implications of domestic court decisionmaking for transnational activity, and noting its affinities with legal realism and the New Haven school of international law. Part III illustrates the governance-oriented approach by applying it to the doctrine of forum non conveniens, using an original dataset of over 200 forum non conveniens decisions made by U.S. district court judges to evaluate this example of transnational judicial governance according to the rule-of-law values of predictability and impartiality. Part IV concludes by using Part III's findings to evaluate the extent to which domestic courts can effectively foster transnational rule of law.

\section{TRANSNATIONAL JUDiCIAL GOVERNANCE}

How do states regulate transnational activity? International law and international relations scholars have emphasized the role of international institutions as tools of global governance, giving rise to a rich literature on the origins and consequences of international rules and international organizations. ${ }^{6}$ However, this preoccupation with international institutions obscures the fact that domestic institutions also play a central role in state regulation of transnational activity. ${ }^{7}$ For example, states often address transnational problems through transgovernmental networks, which involve direct cross-border interactions among national regulatory agencies. ${ }^{8}$ In addition, international political economists have shown that domestic executive and legislative institutions can be key players in "two-level games," in which solutions to international cooperation problems must be negotiated not only among states, but also among domestic political actors within each state. ${ }^{9}$ The concept of transnational judicial governance, which I define as the regulation of transnational activity by domestic courts, draws attention to

available at http://ssrn.com/abstract=705363); and Mary L. Volcansek \& John F. Stack, Jr., eds., Courts Crossing Borders: Blurring the Lines of Sovereignty (2005).

${ }^{6}$ For overviews of this expansive body of literature, see Martin and Simmons (1998) and Keohane and Martin (2003), and Kal Raustiala \& Anne-Marie Slaughter, International Law, International Relations and Compliance, in Handbook of International Relations 538 (Walter Carlsnaes, Thomas Risse \& Beth A. Simmons eds, 2002). Recent contributions by international relations scholars include Gruber (2000), Ikenberry (2001), Koremenos, Lipson and Snidal (2001), Simmons (2000), Simmons and Hopkins (2005) and Von Stein (2005). Recent contributions by international legal scholars include Norman and Trachtman (2005), Goldsmith and Posner (2005) and Raustiala (2005).

${ }^{7}$ It also obscures the fact that private authority plays an important role in global governance, as well understood by a growing number of international relations and private international law scholars. See, e.g. [Büthe 2004; Coen and Thatcher 2005; Hall and Biersteker 2002; Mattli and Büthe 2003, 2005] (international relations); and Paul Schiff Berman, The Globalization of Jurisdiction, 151 U. Pa. L. Rev. 311 (2002) and Ralf Michaels, The Re-State-ment of Non-State Law: The State, Choice of Law, and the Challenge from Global Legal Pluralism, 51 Wayne Law Review 1209 (2005) (private international law).

${ }^{8}$ (Keohane and Nye 1974; Raustiala 2002; Slaughter 2004; Slaughter and Zaring 2006; Whytock 2005)

9 (Evans, Jacobson, and Putnam 1993; Frieden and Martin 2002, 120-126; Putnam 1988) 
the role that domestic legal institutions - including domestic courts and domestic law — play in state regulation of transnational activity. ${ }^{10}$ To clarify the concept, this part of the paper explains the allocative functions of transnational judicial governance; its direct and indirect implications for transnational activity; its highly decentralized structure; and its relationship to the related concepts of transgovernmental networks and the legalization of world politics.

\section{Transnational Judicial Governance and the Authoritative Allocation of Values}

According to David Easton's classic definition, the study of politics is concerned with "the authoritative allocation of values" — - that is, with "authoritative social decisions about how goods, both spiritual and material, are to be distributed."12 In this sense, transnational judicial governance is intrinsically political. To illustrate the types of values that are allocated transnationally by domestic courts, and the nature of the transnational actors among whom these values are allocated, I will briefly discuss four settings in which transnational judicial governance decisionmaking takes place in U.S. federal courts: transnational public law litigation, transnational regulatory litigation, transnational private law litigation, and private international law decisionmaking.

Transnational public law litigation is litigation in which "[p]rivate individuals, government officials, and nations sue one another directly, and are sued directly, in a variety of judicial fora, most prominently domestic courts," based on rights derived from both domestic and international law. ${ }^{13}$ In the United States, the Alien Tort Claims Act (ATCA), ${ }^{14}$ as interpreted

\footnotetext{
${ }^{10}$ The concept thus builds on prior work that has acknowledged the status of domestic courts as global actors. See, e.g., Hannah L. Buxbaum, Transnational Regulatory Litigation, 46 Va. J. Int'1 L. 251, 253 (2006) (noting “the development of national courts as actors within the international community"); Richard A. Falk, The Role of Domestic Courts in the International Legal Order (1964); Tonya L. Putnam, Courts Without Borders? Extraterritoriality as a Mechanism for Global Governance (Mar. 2006) (unpublished paper presented at the annual meeting of the International Studies Association); Anne-Marie Slaughter, A New World Order chap. 2 (2004) (describing transgovernmental networks of judges); Whytock, Domestic Courts and Global Governance, supra note _; and Christopher A. Whytock, Foreign Law, Domestic Courts, and World Politics (Mar. 2006) (unpublished paper presented at the annual conference of the International Studies Association). It also builds on earlier conceptual efforts aimed at consolidating diverse sources of law having implications for transnational activity, beginning with Philip Jessup's famous Storrs Lectures at Yale Law School in 1956. Philip C. Jessup, Transnational Law (1956).

${ }^{11}$ David Easton, The Political System: An Inquiry into the State of Political Science 129 (2d ed. 1971) [hereinafter Easton, Political System].

${ }^{12}$ Easton, Political System, supra note _, at 135. As Easton explains further, the focus is on how "certain things are denied to some people and made accessible to others," id. at 130, and on authoritative "modes for allocating desirable or undesirable things," id. at 132, and on "how [these] authoritative decisions are made and executed for a society." David Easton, An Approach to the Analysis of Political Systems, 9 World Politics 383, 383 (1957). This understanding of transnational judicial governance resonates with the New Haven school's understanding of international law as a global "process of authoritative decision." Myres S. McDougal, Some Basic Theoretical Concepts about International Law: A Policy-Oriented Framework of Inquiry, 4 J. of Conflict Resolution 337, 350 (1960).

${ }^{13}$ Harold Hongju Koh, Transnational Public Law Litigation, 100 Yale L. J. 2347, 2348-2349 (1991). As AnneMarie Slaughter and David Bosco note, "[i]ncreasing numbers of individuals, including torture and terrorism victims, Holocaust survivors, and denizens of the dwindling Amazon rain forest, are now using lawsuits to defend their rights under international law [in U.S. courts]. The defendants in these cases include multinational corporations, foreign government officials, and even foreign states themselves." Anne-Marie Slaughter \& David Bosco, Plaintiff's Diplomacy, Foreign Affairs, Sept./Oct. 2000, at 102.
} 
by the Second Circuit of the U.S. Court of Appeals in Filartiga v. Pena-Irala, ${ }^{15}$ provides the legal foundation for most transnational public law litigation. In that case, two Paraguayan citizens sued a Paraguayan official in U.S. federal court for the politically-motivated killing of a member of their family. ${ }^{16}$ However, private actors may also be subject to liability under ATCA for sufficiently "state-like or state-related activities." 17 Thus, transnational public law litigation has been an increasingly important strategy for human rights protection. When these cases result in the award of compensatory or punitive damages, domestic courts are allocating economic resources among state and nonstate actors. ${ }^{18}$ More fundamentally, these decisions implicate basic values of safety and human dignity. ${ }^{19}$

Transnational regulatory litigation is litigation in which U.S. courts apply U.S. regulatory norms to transnational activity. ${ }^{20}$ For example, domestic courts frequently apply U.S. antitrust law to regulate global cartels and other anticompetitive transnational activity, and U.S. securities laws to regulate cross-border securities fraud. ${ }^{21}$ Underlying these regulations are national policies that authoritatively allocate values among consumers, investors, businesses, and other economic actors; and when U.S. policies allocate these values differently than other states affected by transnational activity, the extraterritorial application of U.S. law to that activity is often controversial. ${ }^{22}$ These values cover a wide variety of policy concerns, including consumer and investor protection, promotion of competitive markets, and provision of capital — which inform antitrust and securities regulation - as well as values such as environmental protection, product safety, public health, and worker safety. More broadly, as Hannah Buxbaum argues,

${ }^{14} 28$ U.S.C. $§ 1350$ (providing that federal district courts have jurisdiction over any civil action brought by an alien for a tort committed in violation of international law).

${ }^{15} 630$ F.2d 876 (2d Cir. 1980).

${ }^{16} \mathrm{Id}$.

${ }^{17}$ Ralph G. Steinhardt, The Internationalization of Domestic Law, in The Alien Tort Claims Act: An Analytical Anthology 3, 9 (Ralph G. Steinhardt and Anthony D’Amato eds., 1999).

${ }^{18}$ However, plaintiffs that are successful in transnational public law litigation against states or state officials rarely are able to fully collect compensation. See Koh, supra note _, at 2368 (noting that "no Filartiga-type plaintiff has apparently collected full compensation for his injuries").

${ }^{19}$ These are among the values identified by Myres McDougal as being allocated by the authoritative decisionmaking that constitutes international law. McDougal, supra note _, at 343, 349.

${ }^{20}$ Hannah Buxbaum coined the term, and is the leading analyst of this type of transnational litigation. Buxbaum defines transnational regulatory litigation as litigation in domestic courts involving the application of domestic regulatory norms that are shared by the international regulatory community to transnational activity, in a manner that provides global regulatory benefits. Hannah L. Buxbaum, Transnational Regulatory Litigation, 46 Va. J. Int'1 L. 251, 268 (2006) For my descriptive purposes, I adopt a broader definition of transnational regulatory jurisdiction, dropping the requirement the domestic regulatory rules that are applied necessarily are shared by the regulatory community or have a beneficial effect on transnational activity. I treat the extent to which these rules are in fact shared and the extent to which they yield global regulatory benefits as open questions to be answered using empirical and normative analysis.

${ }^{21}$ See Buxbaum, supra note _, at 271-278 (antitrust and securities law) and George A. Bermann, Transnational Litigation 237-247 (2003) (antitrust, securities, and maritime law).

${ }^{22}$ See Bermann, supra note _, at 240 (noting that "[i]n countless antitrust cases, federal courts have applied the relevant federal statutes to regulate genuinely multinational scenarios, because of substantial effects in the US, thus arousing objections by foreign parties and foreign governments alike . ..”) and Buxbaum, supra note _, at 268-270 (noting that "the extraterritorial application of domestic law creates substantial conflict between nations" when there are "differences in substance between the law applied and the law of the other country or countries involved ..."). 
these cases not only close gaps in international regulation, but also "give domestic courts a role in the transnational process of articulating and defending global norms."23

Transnational Private Litigation. Just as international relations scholars' preoccupation with international institutions has obscured the role of domestic institutions in global governance, an emphasis on public law, including human rights law as well as explicitly regulatory bodies of law such as antitrust and securities law, runs the risk of obscuring the important role of domestic private law in global governance. According to the widely criticized but widely used public-private law distinction, private law includes the law of torts, contracts, and property. But, as Martin Shapiro argues, private law is just as much an instrument of authoritative value allocation as "public" or "regulatory" law. ${ }^{24}$ Indeed, "[t]he "private' law of property and contract authoritatively allocates most of the values in a capitalist society.",25 Moreover, transnational litigation involving private law matters - which Robert Wai refers to as "transnational private litigation" transnational regulatory litigation. Therefore, from the perspective of transnational judicial governance, transnational private litigation is at least as important as other types of transnational litigation.

The policies underlying private law include compensation for harm, as well as social regulation through provision of public goods, correction of market failures, and deterrence of undesirable activity. ${ }^{27}$ Thus, transnational private litigation can serve both distributive and regulatory functions. ${ }^{28}$ Disputes over property rights - including intellectual property rightsexplicitly involve conflicting claims over economic resources. In such disputes, domestic courts allocate those resources by assigning property rights to one party or another. ${ }^{29}$ Transnational actors enter contracts to reduce their uncertainty about how they will share the costs and benefits of their economic transactions. In contract disputes, domestic courts allocate these costs and benefits by determining how the contract is interpreted and whether it is enforced. ${ }^{30}$ In addition, transnational economic activity may generate externalities; that is, it may have effects on an actor who does not have a contractual relationship with the person engaged in that activity. In

\footnotetext{
${ }^{23}$ Buxbaum, supra note _, at 254.

${ }^{24}$ Martin Shapiro, From Public Law to Public Policy, or the "Public" in "Public Law," 5 PS: Political Science and Politics 410, 413 (1972) (noting, for example, the law of torts, as well as "credit-debtor, landlord-tenant, sellerpurchaser and a host of other areas of [private] law that set the balance of economic power between competing segments of society").

${ }^{25}$ Martin Shapiro, Public Law and Judicial Politics, in Political Science: The State of the Discipline II 365, 366 (Ada W. Finifter ed., 1993).

${ }^{26}$ Robert Wai, Transnational Private Litigation and Transnational Governance, in Criticizing Global Governance 243-261 (Markus Lederer \& Philipp S. Müller eds., 2005) [hereinafter Wai, Transnational Private Litigation].

${ }^{27}$ Robert Wai, Transnational Private Law and Private Ordering in a Contested Global Society, 46 Harv. Int'1 L.J. 471, 474 (2005).

${ }^{28}$ Wai, Transnational Private Litigation, supra note _, at 245.

${ }^{29}$ For discussions of the economics of property law, see e.g., Robert Cooter \& Thomas Ulen, Law and Economics chaps. 4-5 (3d ed. 2000), and Louis Kaplow \& Steven Shavell, Economic Analysis of Law 14-29 (Feb. 1999) (unpublished manuscript, available as National Bureau of Economic Research Working Paper 6960, at http://www.nber.org/papres/w6960).

${ }^{30}$ See, e.g., Joel R. Paul, The Isolation of Private International Law, 7 Wis. Int'1 L.J. 149, 153 (1988) (noting that "[t]he [1] egal realists showed that the rules of classical contract law represent the exercise of public power as much as the rules of antitrust law"). For more general discussions of the economics of tort law, see, e.g., Cooter \& Ulen, supra note _, at chaps. 6-7, and Kaplow \& Shavell, supra note _, at 29-45.
} 
tort disputes, domestic courts allocate the costs of negative externalities among transnational actors by determining the extent to which the party generating the externalities must compensate the party that bears the associated costs. ${ }^{31}$ Finally, at the intersection of transnational public and transnational private litigation are disputes involving the economic activity of sovereign states, including disputes over sovereign $\mathrm{debt}^{32}$ and, more generally, transnational litigation in which a foreign sovereign does not enjoy immunity from suit in U.S. courts under the commercial activity exception of the Foreign Sovereign Immunities Act. ${ }^{33}$

Private International Law Decisionmaking and the Allocation of Governance Authority. First and prior to all other questions about governance, says Miles Kahler, is "Who governs?"34 Three basic types of governance authority are at stake: adjudicative authority, which is the authority of a state to use its courts to resolve disputes involving particular actors or things; prescriptive authority, which is the authority of a state to apply its law to particular actors or activities; and enforcement authority, which is the authority of a state to induce or compel compliance with its law. ${ }^{35}$ In the governance of transnational activity, however, the answer to the "who governs" question rarely is obvious. Because such activity has connections to more than one state, more than one state may have a basis for legitimately exercising the authority to govern it. The challenge is that "law has become the prerogative of territorial sovereigns, whereas human affairs freely cross . . national boundaries."36

In transnational litigation, domestic courts are routinely called upon to answer the "who governs" question and to decide how the three types of governance authority should be allocated among sovereign states. ${ }^{37}$ These decisions correspond to the three main branches of private international law: jurisdiction, choice of law, and recognition and enforcement of foreign judgments. ${ }^{38}$ Yet they share a common domestic-foreign dimension of variation: each decision is

\footnotetext{
${ }^{31}$ See, e.g., Shapiro, supra note _, at 413-414 (noting that tort law "is anxious to define justice between man and man almost exclusively in terms of what treatment of individual litigants will best achieve preferred social goals"). For more general discussions of the economics of tort law, see, e.g., Cooter \& Ulen, supra note _, at chaps. 8-9, and Kaplow \& Shavell, supra note _, at 2-13.

32 See, e.g., G. Mitu Gulati, Lee C. Buchheit \& Robert B. Thompson, The Dilemma of Odious Debts, 57 Duke L. J. (2007).

$\overline{33} 28$ U.S.C. $\S \S 1602-1611$.

${ }^{34}$ Miles Kahler, Global Governance Redefined 3 (Oct. 2004) (unpublished manuscript, available at http://irpshome.ucsd.edu/faculty/mkahler/GlobGov 10.04.doc). See also Mark A. Pollack \& Gregory C. Shaffer, Who Governs? in Transatlantic Governance in the Global Economy 287 (Mark A. Pollack \& Gregory C. Shaffer eds., 2001) and Daniel W. Drezner, Who Rules? The Regulation of Globalization (2005) (unpublished book manuscript available at http://www.danieldrezner.com/research.html).

${ }^{35}$ Barry E. Carter \& Phillip R. Trimble, International Law 699-702 (1991);

${ }^{36}$ Friedrich K. Juenger, Choice of Law and Multistate Justice 3 (special ed. 2005). See also John Gerard Ruggie, Territoriality and Beyond: Problematizing Modernity in International Relations, 47 Int'1 Org. 139, 164 (1993) (explaining what he calls the "paradox of absolute individuation" raised by the territorial approach to sovereignty: "Having established territorially fixed state formations, having insisted that these territorial domains were disjoint and mutually exclusive, and having accepted these conditions as the constitutive bases of international society, what means were left to the new territorial rulers for dealing with problems of society that could not be reduced to territorial solution?").

${ }^{37}$ In addition, these decisions involve the allocation of governance authority among state and nonstate actors. See discussion below, infra at notes _-..

${ }^{38}$ Juenger, supra note _, at 3; Eugene F. Scoles, Peter Hay, Patrick J. Borchers \& Symeon C. Symeonides, Conflict of Laws
} 
either an assertion of domestic authority to govern the underlying transnational activity, or deference to a foreign state's authority to govern that activity. ${ }^{39}$ For example, imagine a dispute arising out of activity with connections to both State A and State B. If the plaintiff brings the dispute before a State A court, should the State A court adjudicate the dispute (assertion of domestic adjudicative authority) or should it dismiss the case so it can be adjudicated by a State B court (deference to foreign adjudicative authority)? If a State A court decides to adjudicate the dispute, should it apply State A law to the underlying transnational activity (assertion of domestic prescriptive authority) or should it apply State B law (deference to foreign prescriptive authority)? And if a State B court adjudicates the dispute, one party may ask a State A court to enforce the State B court's judgment against the other party in State A. Should the State A court refuse to do so (thus asserting the territorial exclusivity of domestic enforcement authority) or should it give domestic effect to the foreign judgment (thus deferring to foreign enforcement authority) $?^{40}$

By deciding between the assertion of domestic governance authority and deference to foreign governance authority over transnational activity, domestic courts help define the domestic reach of foreign authority and the foreign reach of domestic authority. Or, to use international relations scholar Stephen Krasner's terminology, they help define the circumstances

\footnotetext{
${ }^{39}$ To clarify, by "deference" I mean, at a minimum, a decision by a State A court not to assert State A's governance authority, coupled with an affirmation that, under the circumstances, it is appropriate for State B to exercise its authority. Thus, deference implies an understanding by State A that authority should be allocated to State B. The term does not, however, imply that State B is necessarily interested in exercising that authority. For example, a State A court may defer to State B's adjudicative authority by declining to exercise its own adjudicative authority over a lawsuit originally brought in the State A court and dismissing it in favor of a State B court; but State B may or may not actually exercise its authority. On the other hand, declining to assert domestic authority without a corresponding affirmation of a foreign state's authority is mere abstention, not deference, and does not imply an understanding of the appropriate allocation of governance authority. Deference also may be more active. For example, a State A court may defer to State B's prescriptive authority by applying State B's law to transnational activity, and a State A court may defer to State B's enforcement authority by ordering the enforcement within State A territory of a judgment of a State B court.

${ }^{40}$ Situating decisions regarding recognition and enforcement of foreign judgments on the domestic-foreign dimension is more complicated. If a foreign court issues a judgment, it has exercised its own authority to resolve a dispute. In transnational disputes, the problem is that "a judgment will operate in foreign states only if the courts of those states are willing to provide assistance by recognizing or enforcing the judgment: '[a]s an act of government [a judgment's] effects are limited to the territory of the sovereign whose court rendered the judgment, unless some other state is bound by treaty to give the judgment effect in its territory, or unless some other state is willing, for reasons of its own, to give the judgment effect" Born $(1996,936)$. Thus, by refusing to recognize or enforce a foreign judgment, a domestic court is, in effect, asserting the exclusivity of its state's sovereign authority within its territory. Moreover, such refusal typically is based on a determination by the domestic court that the foreign court did not have proper jurisdiction over the dispute, that the defendant did not enjoy certain minimum standards of fairness in the foreign court, or that there the foreign court's judgment is in some other way defective (see Born 1996, 963 et seq.) - in other words, the refusal is based on a displacement of the foreign court's authority with the domestic court's own authority to determine the proper dispute resolution process or outcome. Therefore, I conceive of a domestic court decision refusing the recognition or enforcement of a foreign judgment as an assertion of domestic governance authority. In contrast, when a domestic court recognizes or enforces a foreign court's judgment, it is deferring to foreign governance authority - namely, the authority of the foreign state to conclusively resolve a transnational dispute in its own courts according to its own rules and procedures. It is true that in the case of enforcement, this form of deference depends on a concurrent assertion of domestic enforcement authority in order to give the foreign judgment domestic effect. Nevertheless, the domestic authority is being exercised in support of the foreign judgment. For that reason, I conceive of both recognition and enforcement of a foreign judgment as deference to foreign authority.
} 
in which Westphalian sovereignty is compromised "through invitation." 41 As Michael Reisman puts it, lawyers may 'refer to these encounters as 'conflicts of laws,' but they are, in the most profound sense, conflicts of power, for they engage the very essence of state sovereignty: a

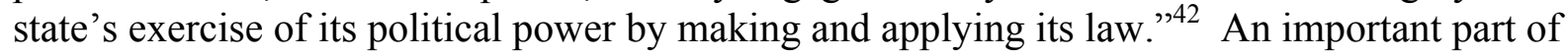
transnational judicial governance is the role of domestic courts in resolving (and sometimes aggravating) these conflicts.

\section{Direct and Indirect Implications}

Transnational judicial governance has direct and indirect implications for transnational activity. For the parties to a particular transnational dispute, the consequences of the allocative decisions just discussed are direct. These direct effects are the focus of litigant-oriented approaches to the study of litigation. Without discounting the importance of litigation outcomes for individual litigants and the study of litigation, the concept of transnational judicial governance is intended to draw attention to the broader implications of domestic law and domestic court decisionmaking for transnational activity. Scholars of domestic litigation have demonstrated the influence that court decisions can have on strategic behavior, which is expressed in the concept of the "shadow of the law." Judicial decisionmaking in transnational litigation casts a transnational shadow, indirectly influencing the behavior of transnational actors beyond a particular dispute. Another way that domestic legal institutions indirectly affect transnational activity is by reinforcing, and sometimes undermining, other forms of governance, including international and private governance.

The Transnational Shadow of Domestic Law. Research on domestic litigation demonstrates that domestic actors bargain "in the shadow of the law."43 That is, actors" expectations about how a court would resolve actual or potential disputes influence their behavior. ${ }^{44}$ The behavior of transnational actors also takes place in the shadow of the lawincluding the domestic law that domestic courts interpret and apply in transnational litigation. Their expectations about how domestic courts will allocate values influence their behavior. ${ }^{45}$

\footnotetext{
${ }^{41}$ Stephen D. Krasner, Sovereignty: Organized Hypocrisy 22 (1999). According to Krasner, the institution of Westphalian sovereignty is based on territoriality and the exclusion of external authority. Id. at 20. The invitation of foreign authority does not violate international legal sovereignty because it is voluntary, but it does violate Westphalian sovereignty. Id. at 22.

${ }^{42}$ Michael W. Reisman, Mahnoush H. Arsanjani, Siegfried Wiessner \& Gayl S. Westerman, International Law in Contemporary Perspective 1381 (2004).

${ }^{43}$ See, e.g., Robert N. Mnookin \& Lewis Kornhauser, Bargaining in the Shadow of the Law: The Case of Divorce, 88 Yale L.J. 950 (1979). A more general strategic model of bargaining in the shadow of the law was developed in Robert Cooter \& Stephen Marks with Robert Mnookin, Bargaining in the Shadow of the Law: A Testable Model of Strategic Behavior, 11 J. Legal Stud. 225 (1982).

${ }^{44}$ See Cooter \& Ulen, supra note _, at 398 ("bargaining occurs in the shadow of the law. In other words, expectations about trials determine the outcomes of bargains").

${ }^{45}$ See, e.g., Marc L. Busch \& Eric Reinhardt, Bargaining in the Shadow of the Law: Early Settlement in GATT/WTO Disputes, 24 Fordham Int'l L.J. 158 (2000) (examining the influence of parties' expectations about WTO dispute resolution mechanism outcomes on international trade). The notion of transnational behavior in the shadow of the law is an example of a strategic choice approach to understanding transnational relations. See David A. Lake \& Robert Powell, International Relations: A Strategic-Choice Approach, in Strategic Choice and International Relations 8-11 (David A. Lake \& Robert Powell eds., 1999) and Helen Milner, Rationalizing Politics: The Emerging Synthesis of International, American, and Comparative Politics, 52 Int'l Org. 69 (1998) (each noting that the behavior of transnational actors depends not only on their preferences, but also on their expectations about
} 
Thus, judicial decisionmaking in transnational litigation has an impact that goes well beyond the parties to a particular dispute. Simply put, domestic law casts a transnational shadow. ${ }^{46}$

The nature of the transnational shadow of domestic law can be understood in terms of the influence domestic law has on the behavior of transnational actors at various stages of their interactions. As Wayne Sandholtz and Alec Stone Sweet explain:

First, at the level of the single actor, a norm can prevent disputes from arising in the first place, by providing individuals with behavioral guidance, and by structuring choices concerning compliance. Second, once a dispute has erupted, norms may provide the ... parties with the materials for settling the dispute on their own . . . to the extent that norms furnish the bases for evaluating both the disputed behavior and potential solutions to the conflict. Third, existing rule systems help third-party dispute resolvers do their jobs, by providing templates for determining the nature of the dispute and an appropriate solution. ${ }^{47}$

When domestic courts interpret and apply domestic law to transnational activity, the effects on transnational activity are likewise both direct and indirect. "When a judge decides, the

what other actors will do). However, the shadow of the law can also be understood in terms of normative influence, with domestic law and domestic courts clarifying norms of transnational behavior. See James G. March \& Johan P. Olsen, The Institutional Dynamics of International Political Orders, 52 Int'1 Org. 943, 951 (distinguishing the behavioral logic of consequences from the logic of appropriateness, according to which transnational "[a]ction involves evoking an identity or role and matching the obligations of that identity or role to a specific situation") and Wayne Sandholtz \& Alec Stone Sweet, Law, Politics, and International Governance, in The Politics of International Law 238 (Christian Reus-Smit ed., 2004) (distinguishing between the material-physical power and the normativeideational power of international law). In effect, the influence of the shadow of the law on transnational actors is analogous to questions raised in the international compliance literature about how international law may affect state behavior. See Kal Raustiala \& Anne-Marie Slaughter, International Law, International Relations and Compliance, in Handbook of International Relations 538 (Walter Carlsnaes, Thomas Risse \& Beth A. Simmons eds., 2002) (providing an overview of the international compliance literature) and Christopher A. Whytock, Thinking Beyond the Domestic-International Divide: Toward a Unified Concept of Public Law, 36 Geo. J. Int'1 L. 155 (2004) (arguing that the processes by which law influences behavior are similar for domestic law and international law).

${ }^{46}$ Cf. Samuel P. Baumgartner, "Is Transnational Litigation Different?” 25 U. Pa. J. Int'1 Econ. L. 1297, 1305 (2004) (arguing that "the law applicable to transnational litigation," which is primarily domestic law, "affects the behavior of transnational actors"); Thomas Risse-Kappen, Bringing Transnational Relations Back In, in Bringing Transnational Relations Back In: Non-State Actors, Domestic Structures and International Institutions 3, 25 (Thomas Risse-Kappen ed., 1995) (arguing that "domestic structures mediate, filter, and refract the efforts by transnational actors and alliances to influence policies"); and Anne-Marie Slaughter Burley, International Law and International Relations Theory: A Dual Agenda, 87 Am. J. Int'1 L. 205, 230 (1993) ("transnational law [defined as including domestic law that applies to transnational activity] helps structure patterns of individual and group interaction in transnational society, patterns that in turn generate interest that shape and constrain state action"). In addition, domestic law indirectly affects state compliance with international law. Domestic actors may constitute "compliance constituencies" that either favor or disfavor compliance with international law, depending on their interests. Xinyuan Dai, Why Comply? The Domestic Constituency Mechanism, 59 Int'l Org. 363 (2005); Miles Kahler, Conclusion: The Causes and Consequences of Legalization, 54 Int'1 Org. 661 (2000). Domestic law, in turn, is what "constitutes, empowers, and mobilizes" such groups, "from trade unions, to professional organizations, to business groups, to environmentalists and human rights activists." Martha Finnemore \& Stephen J. Toope, Alternatives to "Legalization": Richer Views of Law and Politics, 55 Int'l Org. 743, 754 (2001).

${ }^{47}$ Wayne Sandholtz \& Alec Stone Sweet, Law, Politics, and International Governance, in The Politics of International Law 238, 245 (Christian Reus-Smit ed., 2004). Although part of a chapter on international law, their reasoning applies equally well to the influence of domestic law on transnational behavior. See id. at 269 ("we deny any inherent, theoretically significant, distinction between how international and domestic regimes operate"). 
lawmaking effect of the decision is always twofold. First, in settling the dispute at hand, the judge produces a legal act that is particular (it binds the two disputants) and retrospective (it resolves an existing dispute). Second, in justifying the decision, the judge signals that she will settle similar cases similarly in the future; this legal act is a general and prospective one (it affects future and potential contractants)." ${ }^{\circ 8}$ As Barry Friedman notes, "In judicial opinions are found the rules that govern the next case, and thus the conduct of institutions and actors in society." 49

As the earlier discussion of private law's distributive and regulatory functions suggests, domestic law and domestic court decisions applying that law to transnational activity—for example, in transnational regulatory or transnational private litigation - may have important indirect effects on transnational economic activity ${ }^{50}$ including foreign investment ${ }^{51}$ and international trade. ${ }^{52}$ Likewise, transnational public law litigation may have important effects that go beyond the parties to a particular dispute. In fact, Harold Koh argues that often the

\footnotetext{
${ }^{48}$ Alec Stone Sweet \& Thomas L. Brunell, Constructing a Supranational Constitution: Dispute Resolution and Governance in the European Community, 92 Am. Pol. Sci. Rev. 63, 64 (1998). As Sandholtz and Stone Sweet $(2004,245)$ explain, "a norm can prevent disputes from arising in the first place, by providing individuals with behavioral guidance, and by structuring choices concerning compliance.... [O]nce a dispute has erupted, norms may provide the contracting parties with the materials for settling the dispute on their own, dyadically as it were, to the extent that norms furnish the bases for evaluating both the disputed behavior and potential solutions to the conflict."

${ }^{49}$ Barry Friedman, Taking Law Seriously, 4 Perspectives on Politics 266 (2006). See also Martin Shapiro \& Alec Stone Sweet, On Law, Politics, and Judicialization 213 (2002) ("[b]argaining is facilitated by the knowledge of each party that, if the two do not reach a consensual resolution to the conflict, the other may go to court and seek an imposed outcome. Just as important, the previously judicially announced rules that will determine what a court will impose if litigation does occur fix the parameters within which the two parties bargain even if neither ever goes to court. The relative legal strengths of the two parties, as defined by those rules judicially announced to resolve previously litigated disputes, are crucial factors in determining the bargaining strengths of negotiating parties in other disputes that are not litigated but, in form, are resolved by purely private, consensual agreements").

${ }^{50}$ See discussion at supra, notes ___. See also Shapiro, supra note _, at 367 ("Some political scientists are studying multinationals and international trade policy. Both public and private international law ... play major roles in these areas. But even as law-oriented political science moves to take up international law again, its preoccupation with public law and with individual rights analogical to our first ten amendment rights will prevent it from promptly rendering the assistance it ought to be giving to political scientists studying international political economy"); Slaughter Burley, supra note _, at 321 ("[H]ow do domestic doctrines encourage or discourage transnational economic interaction? ... [One] line of inquiry would link the political findings on the value of stability to the traditional system of conflicts of law, which long recognized the importance of stable expectations in fostering transnational commerce"); and Christopher A. Whytock, Taking Causality Seriously in Comparative Constitutional Law: Insights from Comparative Politics and Comparative Political Economy 16-17 (Aug. 2006) (unpublished manuscript, available at http://ssrn.com/abstract=926867) (discussing empirical research by comparative political economists showing the impact of domestic legal institutions on transnational economic activity).

${ }^{51}$ See, e.g., Rafael La Porta et al., Law and Finance, 106 J. Pol. Econ. 1113 (1998) (demonstrating the effects of domestic law on foreign investment) and Dani Rodrik, Feasible Globalizations 11-12 (Sept. 2002) (unpublished manuscript, available as National Bureau of Economic Research Working Paper 9129, available at http://www.nber.org/papers/w9129) (noting that "[d]omestic courts may be unwilling - and international courts unable - to enforce a contract signed between residents of two countries" and arguing that "[a] key reason why more capital does not flow to poorer countries is that there is no good way that such a promise can be binding across national jurisdictions - short of resorting to the gunboat diplomacy of old").

${ }^{52}$ See, e.g., Daniel Berkowitz et al., Legal Institutions and International Trade Flows, 26 Mich. J. Int'1 L. 163 (2004) (demonstrating the impact of domestic law on international trade flows) and Baumgartner, supra note _, at 1363 (noting concern among European Union policymakers about the adverse trade consequences of rules governing the enforcement of foreign judgments).
} 
prospective consequences of human rights litigation in domestic courts are more important strategically than its retrospective consequences: "Although [transnational public law plaintiffs"] announced aim has been retrospective redress, the underlying focus of their actions has been prospective: to provoke a judicial declaration that the conduct of United States or foreign government officials violates a norm of international law. To the extent that plaintiffs have won such judicial declarations, they have sought to use them primarily as political constraints upon the defendants' future conduct." 53

In addition, private international law decisionmaking - decisionmaking that allocates governance authority among sovereign states - has important indirect effects. ${ }^{54}$ For example, because transnational activity has connections to more than one state, actors may be uncertain about which state's laws are applicable to their cross-border activities. When domestic courts make decisions allocating prescriptive authority in a particular case, they increase predictability by providing information about applicable law, making it more likely that transnational actors will conform their conduct to the law of one state or another (or deliberately seek to avoid that law). ${ }^{55}$ Similarly, jurisdictional decisions provide information that influences "forum shopping" by transnational actors. ${ }^{56}$ When deciding where to file their lawsuits, plaintiffs consider, among other things, which state's laws are most favorable to their claim. For example, if the plaintiff is

\footnotetext{
${ }^{53}$ Koh, supra note _, at 2369. "As in traditional domestic litigation, transnational public lawsuits focus retrospectively upon achieving compensation and redress for individual victims. But as in traditional international law litigation, the transnational public law plaintiff pursues a prospective aim as well: to provoke judicial articulation of a norm of transnational law, with an eye toward using that declaration to promote a political settlement in which both governmental and nongovernmental entities will participate. Thus, although transnational public law plaintiffs routinely request retrospective damages or even prospective injunctive relief, their broader strategic goals are often served by a declaratory or default judgment announcing that a transnational norm has been violated. Even a judgment that the plaintiff cannot enforce against the defendant in the rendering forum empowers the plaintiff by creating a bargaining chip for use in other political fora." Id. at 2349. As for domestic court decisionmaking in transnational public law litigation, "Although they claim to be resolving disputes in one case only, [judges] are actually declaring (or not declaring) international norms that litigants transport to other fora for use in political bargaining. ... By weaving the doctrinal tapestry that creates, for example, the American Law of Foreign Sovereignty, they determine the jurisdictional boundaries and conflicts that help shape geopolitical and economic relationships among America and its global partners. Although judges seek to avoid playing roles in international politics, they inevitably do so both by deciding cases and by not deciding them. Although they may claim to be avoiding politics by not deciding cases under international law, such 'non-decisions' frequently ally them with the forces of violence." Id. at 2395.

${ }^{54}$ There is a growing literature that applies a law and economics framework of analysis to understand the effects of private international law on the behavior of transnational actors and to prescribe ways that private international law-including domestic rules governing jurisdiction, choice of law, and recognition of foreign judgments - could be improved. See, e.g., Ralf Michaels, Two Economists, Three Opinions? Economic Models for Private International Law-Cross-Border Torts as Example, in An Economic Analysis of Private International Law 143-184 (Jürgen Basedow \& Toshiyuki Kono eds., 2006); Andrew T. Guzman, Choice of Law: New Foundations, 90 Geo. L.J. 883 (2002); Giesela Rühl, Methods and Approaches in Choice of Law: An Economic Perspective, 24 Berk. J. Int'1 L. _(2006); Joel P. Trachtman, Economic Analysis of Prescriptive Jurisdiction, 42 Va. J. Int'1 L. 1 (2001); Michael J. Whincop \& Mary Keyes, Policy and Pragmatism in Conflict of Laws (2001). This literature builds on earlier economic analyses of domestic choice of law, including Erin Ann O'Hara \& Larry E. Ribstein, Conflict of Laws and Choice of Law, in Encyclopedia of Law and Economics (Boudewijn Bouckaert \& Gerrit De Geest eds., 1999) [available at http://encyclo.findlaw.com] and Erin A. O'Hara \& Larry E. Ribstein, From Politics to Efficiency in Choice of Law, 67 U. Chi. L. Rev. 1151 (2000).

${ }^{55}$ Lea Brilmayer, Conflict of Laws: Foundations and Future Directions 167-175 (1991); Rühl, supra note _, at 9-10, 22.

${ }^{56}$ Rühl, supra note _, at 11-15.
} 
more likely to win under State A's law than under State B's law, the plaintiff may file its lawsuit in a State A court, even if the transnational activity giving rise to the dispute occurred primarily in State B. Prior State A court decisions in similar circumstances applying the law of the place of the underlying transnational activity rather than its own law would discourage this form of forum shopping, as would State A court decisions dismissing similar cases that arise from activity occurring outside State A territory. ${ }^{57}$ In summary, although typically labeled as "procedural," these decisions affect the substantive rights and the behavior not only of the parties to a particular dispute, but also of other transnational actors acting in the transnational shadow of domestic law. ${ }^{58}$

Transnational Judicial Governance and Other Forms of Governance. Transnational judicial governance also indirectly affects transnational activity by facilitating or hindering alternative approaches to global governance. ${ }^{59}$ International legal scholars and international relations scholars have emphasized the role of formal interstate institutions, including international treaties, as tools of global governance. ${ }^{60}$ To a great extent, however, the effectiveness of international institutions depends on domestic legal institutions. For example, by applying international law to transnational disputes, domestic courts enhance the effectiveness of formal international governance arrangements; by declining to do so, they limit the effectiveness of these arrangements. ${ }^{61}$ Similarly, domestic courts can support private governance by enforcing contracts. Transnational activity generates transnational conflict which in turn creates a demand for transnational third-party dispute resolution. ${ }^{62}$ Without third-party dispute resolution, "the costs of exchanges may be prohibitive, since each prospective party may doubt that the other will abide by promises made over the life of a contract." ${ }^{3}$ By providing transnational dispute resolution services, domestic courts help meet this demand, providing an important global public good that enhances contracting as a form of private governance. ${ }^{64}$ Likewise, domestic courts can support arbitration as a form of private dispute resolution by enforcing arbitration agreements and arbitral decisions - or they can undermine it by declining to

\footnotetext{
${ }^{57}$ For discussions of how rules allocating adjudicative and prescriptive authority can affect strategic behavior, see Brilmayer (1991, 167-175), O’Hara and Ribstein (1999, 634-635), and Whincop and Keyes (26-30).

${ }^{58}$ Samuel P. Baumgartner, “Is Transnational Litigation Different?” 25 U. Pa. J. Int'1 Econ. L. 1297, 1298-1299 (2004).

${ }^{59}$ For comparisons of interstate, transgovernmental and private governance, see Mark A. Pollack \& Gregory C. Shaffer, eds., Transatlantic Governance in the Global Economy (2001) and Whytock, supra note _, at 5-12.

${ }^{60}$ Supra, note_.

${ }^{61}$ See Buxbaum, supra note _, at 254 (noting that transnational public law litigation often involves "marshaling the resources of national courts in order to enhance global compliance with international law"); Lea Brilmayer, International Law in American Courts: A Modest Proposal, 100 Yale L.J. 2277 (1991) (discussing the role of domestic courts in the enforcement of international law); Robert O. Keohane, Andrew Moravcsik \& Anne-Marie Slaughter, Legalized Dispute Resolution: Interstate and Transnational, 54 Int'l Org. 457 (2000) (same); and Harold Hongju Koh, Bringing International Law Home, Hous. L. Rev. 623 (1998) (same).

${ }^{62}$ Stone Sweet \& Brunell, supra note _, at 63-64.

${ }^{63}$ Id. at 64.

${ }^{64}$ As Robert Wai argues, one consequence of this is the potential for "transnational liftoff of international business transactions from national regulatory oversight.” Robert Wai, 40 Colum. J. Transnat'1 L. 209, 212 (2002). See also Joel R. Paul, The Isolation of Private International Law, 7 Wis. Int'1 L.J. 149, 152 (1988) (noting that "[t]he judicial enforcement of pre-dispute arbitration agreements in international contracts, even where national law prohibits arbitration of certain statutory causes of action, allows some private parties to exempt themselves from public regulation of certain transactions").
} 
do so. ${ }^{65}$ As Anne-Marie Slaughter puts it, "the availability of judicial enforcement - the coercive apparatus of the State - undergirds the entire system of international commercial arbitration."66

\section{The Decentralized Structure of Transnational Judicial Governance}

One of the ways that different forms of governance vary is according to the extent to which authority is centralized. As Kahler and Lake explain, "[a]uthority can be highly concentrated - vested in a single, hierarchical entity with claims to exclusive jurisdiction .... Governance can also be widely dispersed among individual nodes exercising only limited jurisdiction. ${ }^{, 67}$ Transnational judicial governance is characterized by an extremely low degree of centralization. It consists of domestic courts around the world acting as global governors, allocating values among transnational actors and governance authority among states. They do so independently, and although there are a number of bilateral and multilateral agreements dealing with private international law matters, transnational judicial governance takes place outside the context of any overarching hierarchical arrangement. ${ }^{68}$

Given the highly decentralized nature of transnational judicial governance, the limited ability of domestic courts to unilaterally allocate governance authority needs to be emphasized, even though international legal scholars commonly use the term "allocation" to refer to the distribution of adjudicative, prescriptive and enforcement authority among states. ${ }^{69}$ Even if a State A court asserts its own governance authority over a particular transnational activity, it cannot prevent State B from also asserting authority over that activity. There is not "an impartial mechanism of hierarchically superior authority for resolving such conflicts." ${ }^{, 70}$ Conversely, even if State A defers to State B's governance authority, it cannot compel State B to exercise that authority. How authority actually is allocated ultimately is the aggregate result of decisions by courts of multiple states. Thus, authority allocation generally should be understood as a collective function, although not necessarily a coordinated function, of transnational judicial governance. $^{71}$

\footnotetext{
${ }^{65}$ For an overview of the rules governing the enforcement of arbitration agreements and arbitral awards, see Gary B. Born, International Civil Litigation in United States Courts: Commentary and Materials chap. _ (3d ed. 1996).

${ }^{66}$ Anne-Marie Slaughter, International Law in a World of Liberal States, 6 Eur. J. Int'1 L. 503, 519 (1995). See also Slaughter Burley, supra note _, at 232 (highlighting "the intersection of the public and private spheres underpinning a law that formally regulates individual merchants outside national legal systems but is ultimately dependent on them").

${ }^{67}$ Kahler \& Lake, supra note _, at 8.

${ }^{68}$ Transnational judicial governance also is decentralized in another sense: domestic courts generally can only hear cases that are brought to them by other actors who file their suits as plaintiffs. See Jack Knight \& James Johnson, The Priority of Democracy: A Pragmatist Approach to Political-Economic Institutions and the Burden of Justification, 101 Am. Pol. Sci. Rev. 47, 58 (2007) (noting that "the agenda setting power in judicial institutions is largely exogenous. Although judges often are authorized to refuse to hear various kinds of cases, they typically cannot initiate causes of action. The must instead rely on interested parties to bring controversies before the court."). However, "it is nevertheless the machinery of the state that transnational litigation uses to achieve a regulatory end.” Buxbaum, supra note _, at 304.

${ }^{69}$ See, e.g., Carter \& Trimble, supra note _, at 699-700; Reisman et al., supra note _, at 1381-1383; and Joseph Modeste Sweeney, Covey T. Oliver \& Noyes E. Leech, Cases and Materials on the International Legal System 8283 (3d ed. 1988).

${ }^{70}$ Scoles, Hay, Borchers \& Symeonides, supra note _, at 2.

${ }^{71}$ As Easton stresses, the authoritative allocation of values "does not imply or assume that a central governmental organization is required in order to make decisions and effectuate them. Institutional devices for making and
} 
Transnational Judicial Governance, Transgovernmental Networks, and the Legalization of World Politics

Finally, the nature of transnational judicial governance can be clarified by comparing it to two related concepts: transgovernmental networks and the legalization of world politics. Transnational judicial governance may sometimes take the form of transgovernmental relations, defined by Robert Keohane and Joseph Nye as "sets of direct interactions among subunits of different governments that are not controlled or closely guided by the policies of the cabinets or chief executives of those governments,"72 or transgovernmental networks, defined by AnneMarie Slaughter as "pattern[s] of regular and purposive relations among like government units working across . . . borders." 73 Often, however-perhaps most of the time-domestic courts make transnational judicial governance decisions outside the context of any network of regular and purposive relations with foreign courts. Without diminishing the significance of transjudicial communication and transgovernmental networks of judges as emerging forms of global governance, my impression is that most transnational judicial governance decisions are made by busy trial court judges that generally will not have the time or resources to consult with foreign counterparts before making decisions having transnational implications. ${ }^{74}$

Transnational judicial governance also is related to but distinct from what Kenneth Abbott, Robert Keohane, Andrew Moravcsik, Anne-Marie Slaughter and Duncan Snidal conceptualize as the legalization of world politics. ${ }^{75}$ They define legalization as "a particular set of characteristics that institutions may (or may not) possess": obligation, precision, and

executing policy may take an infinite variety of forms." Easton, Political System, supra note _, at 137. For this reason, he deemed it appropriate to conceive of international politics as well as domestic politics in terms of authoritative allocation of values. Id. at 138-141. A process of authoritative allocation of values can exist "even though the devices may be less formal and even though there may be few, if any, legally recognized means for enforcing decisions. The form of the mechanism and the kind of sanctions are, however, matters for empirical investigation; they do not invalidate the conclusion that there is discernible a process whereby values are authoritatively allocated for the whole society." Id. at 141.

${ }^{72}$ Robert O. Keohane \& Joseph S. Nye, Transgovernmental Relations and International Organizations, 27 World Pol. 39, 43 (1974).

${ }^{73}$ Anne-Marie Slaughter, A New World Order 14 and chap. 2 (2004). See also Anne-Marie Slaughter, A Typology of Transjudicial Communication, 29 U. of Rich. L. Rev. 99 (1994) (on "transjudicial communication") and Melissa A. Waters, Mediating Norms and Identity: The Role of Transnational Judicial Dialogue in Creating and Enforcing International Law, 93 Geo. L.J. 487 (2005) (on "transnational judicial communication"). For a review of the literature on transgovernmental networks, see Slaughter \& Zaring, supra note

${ }^{74}$ In other words, it may be true, as Anne-Marie Slaughter notes, that there is an "increasing ability for transnational disputes to be resolved in ... several forums that are coordinating with one another." Slaughter, New World Order, supra note _, at 102. For example, as Jay Westbrook has documented, there are instances of direct interactions between U.S. and foreign courts in cross-border insolvency proceedings. Jay Lawrence Westbrook, International Judicial Negotiation, 38 Tex. Int'1 L.J. 567 (2003). However, I am not convinced, based on the available evidence, that this type of coordination is widespread, at least insofar as it involves U.S. district courts, nor am I convinced that such coordination, however desirable it might be, is likely to become routine in the immediate future given the intense workload and limited resources of district court judges. Eventually, however, perhaps district court judges will find that transgovernmental cooperation may be a way of increasing the efficiency with which they resolve transnational disputes.

${ }^{75}$ Kenneth W. Abbott, Robert O. Keohane, Andrew Moravcsik, Anne-Marie Slaughter \& Duncan Snidal, The Concept of Legalization, 54 Int'l Org. 401 (2000). 
delegation. ${ }^{76}$ According to their concept, "[o]bligation means that states or other actors are bound by a rule or commitment or by a set of rules or commitments. ... Precision means that rules unambiguously define the conduct they require, authorize, or proscribe. Delegation means that third parties have been granted authority to implement, interpret, and apply the rules; to resolve disputes; and (possibly) to make further rules." ${ }^{, 77}$ Like legalized institutions, transnational judicial governance involves the setting, application and enforcement of rules that often have relatively high levels of obligation and precision, and it implies high levels of delegation, given that domestic courts have the authority to determine which state's rules apply to transnational activity and to interpret and implement those rules. Thus, both concepts are about the role of "legalized" institutions in world politics. However, Abbott et al. emphasize the international institutional foundations of legalized world politics, ${ }^{78}$ whereas the institutional foundations of transnational judicial governance are principally domestic - namely, domestic courts and domestic law, including the domestic rules of private international law. ${ }^{79}$ Conceptually speaking, transnational judicial governance nevertheless might be considered an example of the legalization of world politics; Abbott et al.'s focus on international institutions may simply be a matter of empirical emphasis. But the more important point of this comparison is that the legalization of world politics does not necessarily require highly legalized international institutions. ${ }^{80}$ More broadly, the point is that global governance cannot be fully understood without examining its domestic legal foundations. The concept of transnational judicial governance provides a point of departure for studying those foundations.

\section{GOVERNANCE-ORIENTED ANALYSIS OF TRANSNATIONAL LAW}

Notwithstanding the important role of domestic courts in global governance, we know very little about how domestic courts actually behave as global governors and why they govern the way they do. Few legal scholars have engaged in systematic empirical research on private international law, ${ }^{81}$ and political scientists studying judicial behavior have focused almost

\footnotetext{
${ }^{76}$ Id. at 37.

${ }^{77} \mathrm{Id}$.

${ }^{78}$ See id. at 406, Table 1 (listing international institutions). However, at least one contribution to the special issue of International Organization that introduced the legalization concept stresses the role that domestic courts play in the domestic enforcement of international norms. See Keohane et al., supra note _.

${ }^{79}$ Another way of putting it is that even when an international institution's level of delegation is low, it generally will be more centralized than transnational judicial governance in the sense that its rules, unlike most rules of private international law, are agreed upon by member states. Critics of the legalization concept have called for greater attention to be paid to domestic law. Finnemore \& Toope, supra note _, at 754 . But even their critique neglects private international law, which is the primarily domestic body of law that guides courts as they engage in transnational judicial governance.

${ }^{80}$ Alternatively, if transnational judicial governance is itself treated as an international institution, the point would be that international institutions with very low levels of centralization may be able to impart disproportionately high levels of legalization to transnational relations.

${ }^{81}$ Kevin Clermont and Theodore Eisenberg's 1996 study of foreign parties in U.S. courts might be considered an exception. Kevin M. Clermont \& Theodore Eisenberg, Xenophilia in American Courts, 109 Harv. L. Rev. 1120 (1996). In contrast, there have been several systematic empirical studies of domestic conflict of laws decisionmaking in U.S. courts. See Patrick J. Borchers, The Choice-of-Law Revolution: An Empirical Study, 49 Wash. \& Lee L. Rev. 357 (1992), Michael E. Solimine, An Economic and Empirical Analysis of Choice of Law, 24 Georgia L. Rev. 49 (1989), and Stuart E. Thiel, Choice of Law and the Home-Court Advantage: Evidence, 2 Am. L. \& Econ. Rev. 291 (2000).
} 
exclusively on matters of domestic policy. ${ }^{82}$ For their part, international relations scholars have virtually ignored private international law and domestic courts. ${ }^{83}$ This lack of knowledge is significant not only because it limits our understanding of transnational legal processes, but also because it limits our ability to evaluate critically the real-world consequences of transnational law, including how it actually is applied by courts and how it affects the behavior of transnational actors. The goal of the governance-oriented approach to transnational law is to improve our knowledge of transnational judicial governance, both descriptively and causally, and to begin construction of an empirical foundation for normative analysis of transnational law in action. This part of the paper explains the governance-oriented approach by describing its two principal features, namely its focus on transnational law in action and its focus on the broad implications of domestic court decisionmaking for transnational activity, and by highlighting its affinities with legal realism and the New Haven school of international law.

\section{Focus on Transnational Law in Action: Governance-Oriented Analysis as Complement to Doctrinal Analysis}

International law and international relations scholars generally have emphasized the role of international institutions, including international rules and international organizations, as the main instruments that states use to regulate transnational activity. Resisting this preoccupation with interstate forms of governance, Philip Jessup argued in 1956 for an alternative conception of "the law applicable to the complex interrelated world community." 84 Jessup pointed out that "the term 'international' is misleading since it suggests that one is concerned only with the relations of one nation (or state) to other nations (or states). ${ }^{85}$ In its place, he proposed the

\footnotetext{
${ }^{82}$ Exceptions include studies on U.S. federal court decisionmaking in matters involving human rights, Jeffrey Davis, Justice Without Borders: Human Rights Cases in U.S. Courts, 28 Law \& Policy 60 (2006), and international trade, Isaac Unah, The Courts of International Trade: Judicial Specialization, Expertise, and Bureaucratic Policy-Making (1998).

${ }^{83}$ See Baumgartner, supra note _, at 1384-1385 (“'[b]ecause international relations scholars have paid relatively little attention to [transnational] litigation procedure, the pathways through which such procedure may affect the behavior of groups and individuals as well as that of states - particularly procedural law's correlation with transnational economic interaction - are still relatively poorly understood and thus would offer interesting avenues of research for international relations scholars interested in the transnational litigation setting"). This general lack of attention has persisted notwithstanding calls by Martin Shapiro and Anne-Marie Slaughter in the 1990s for political scientists to explore the implications of private international law. Shapiro, supra note _, at 367; Slaughter Burley, supra note , at 231. To date, one of the only examples of systematic empirical work on judicial behavior by an international relations scholar is Tonya Putnam's important and innovative study of extraterritorial application of U.S. statutory and constitutional rules by U.S. federal courts. Tonya L. Putnam, Courts Without Borders? Extraterritoriality as a Mechanism for Global Governance, paper presented at the annual meeting of the International Studies Association, March 22, 2006. See also Whytock, Transnational Judicial Governance, supra note _ (an empirical analysis of forum non conveniens decisionmaking by U.S. district courts from the perspective of international relations theory). In addition, there has been theoretical and qualitative work by international relations scholars on the role of domestic courts in European integration. See, e.g., Karen Alter, Establishing the Supremacy of European law: The Making of an International Rule of Law in Europe (2001); Anne-Marie Burley \& Walter Mattli, Europe Before the Court: A Political Theory of Legal Integration, 47 Int'l Org. 41 (1993); Alec Stone Sweet \& Thomas L. Brunell, Constructing a Supranational Constitution: Dispute Resolution and Governance in the European Community, $92 \mathrm{Am}$. Pol. Sci. Rev. 63 (1998). In contrast, international relations scholars are increasingly interested in international courts. See, e.g., Alter, supra note _, Cichowski, supra note _, Voeten, supra note _, and Volcanoes \& Stack, supra note _. ${ }^{84}$ Philip C. Jessup, Transnational Law 1 (1956).

${ }^{85}$ Id. Interestingly, it was only some time later that American international relations scholars made a similar critique of then-mainstream international relations theory, proposing a "world politics" approach encompassing not only
} 
concept of "transnational law," which he defined as the body of law "which regulates actions or events that transcend national frontiers," a concept meant to embody both public and private international law. ${ }^{86}$ Challenging the distinction between national and international as a basis for legal classification, he explicitly included in his definition domestic legal rules that apply to transnational activity. ${ }^{87}$

The governance-oriented approach involves not only doctrinal analysis of transnational law, but also empirical and normative analysis of transnational law in action - that is, transnational law as it is actually applied by domestic courts to allocate values among transnational actors. ${ }^{88}$ This is important for several reasons. First, because transnational judicial governance is a form of judicial behavior-namely, domestic courts behaving as global governors - the focus on law in action is necessary as a descriptive matter, for it is not plausible to assume that legal doctrine alone fully describes this behavior. To pursue its descriptive goal, the governance-oriented approach deploys standard methods of descriptive inference to identify broad patterns of judicial decisionmaking in transnational litigation. ${ }^{89}$ Second, the focus on transnational law in action is important for explaining why domestic courts behave the way they do as global governors, for it is not plausible to assume that legal doctrine is necessarily the only determinant of judicial decisionmaking in transnational litigation. ${ }^{90}$ To pursue its explanatory goal, the governance-oriented approach relies on both qualitative and statistical methods of causal inference. ${ }^{91}$ In both of these ways, the governance-oriented approach has an affinity with legal realism, ${ }^{92}$ extending core realist insights to transnational law. ${ }^{93}$ Third, the focus on

interstate relations, but also transnational relations_- "contacts, coalitions, and interactions across state boundaries that are not controlled by the central foreign policy organs of governments.” Joseph S. Nye, Jr., \& Robert O. Keohane, Transnational Relations and World Politics: An Introduction, 25 Int'1 Org. 329, 331 (1971).

${ }^{86}$ Id. at 2. Anne-Marie Slaughter proposes a narrower definition of transnational law: "all municipal law and a subset of intergovernmental agreements that directly regulate transnational activity between individuals and between individuals and state governments." Anne-Marie Slaughter Burley, 87 Am. J. Int'1 L. 205, 230 (1993). Because I understand transnational judicial governance as encompassing the role of domestic courts in the governance of activity involving only states _ as in some instances of transnational public law litigation (see Koh, supra note _, at _), I use Jessup's definition. See also Peer Zumbansen, Transnational Law, in Encyclopedia of Comparative Law 738 (Jan Smits ed., 2006) (providing an overview of the development of the concept of transnational law).

${ }^{87}$ Id. at 70 and 106.

${ }^{88}$ See Roscoe Pound, Law in Books and Law in Action, 44 Am. L. Rev. ,, 15 (1910) ("if we look closely, distinctions between law in the books and law in action, between the rules that purport to govern the relations of man and man and those that in fact govern them, will appear, and it will be found that today also the distinction between legal theory and judicial administration is often a very real and a very deep one").

${ }^{89}$ See Gary King, Robert O. Keohane \& Sidney Verba, Designing Social Inquiry chap. 2 (1994) and Lee Epstein \& Gary King, The Rules of Inference, 69 U. Chic. L. Rev. 1, 29-34 (2002) (explaining basic methods of descriptive inference).

${ }^{90}$ To the contrary, in addition to skeptics in the legal academy ranging from legal realists to critical legal scholars, a substantial body of judicial decisionmaking research provides strong evidence that legal doctrine is not the only explanatory factor. See, e.g., Tracey E. George \& Lee Epstein, On the Nature of Supreme Court Decision Making, 86 Am. Pol. Sci. Rev. 323 (1991) (providing an overview of the literature and a nuanced empirical analysis) and Barry Friedman, Taking Law Seriously, 4 Perspectives on Politics 261 (2006) (criticizing the excessive skepticism about law's influence that pervades much of the political science literature on judicial decisionmaking).

${ }^{91}$ See King et al., supra note _, chap. 3, and Epstein \& King, supra note _, at 34-37 (explaining basic methods of causal inference).

${ }^{9}$ See Karl N. Llewellyn, Some Realism about Realism: Responding to Dean Pound, 44 Harv. L. Rev. 1222, $1236-$ 1237 (1931) (attributing to the legal realist movement a "[d]istrust of traditional legal rules and concepts insofar as they purport to describe what either courts or people are actually doing" and a "distrust of the theory that traditional 
transnational law in action is normatively important. As explained above, judicial decisionmaking in transnational litigation has not only direct effects on the litigants to particular disputes, but also broad indirect implications for transnational relations more generally. ${ }^{94}$ Transnational legal decisionmaking therefore demands critical assessment just as much as transnational legal doctrine does. ${ }^{95}$ There is again an affinity with legal realism - " $[\mathrm{w}] \mathrm{e}$ first must determine how law is working, so that when we set forth our own ideals, we can say how present law is actually fitted to them" law, which seeks to provide, "in lieu of anecdotal historicism, for the systematic description of past trends in decision in terms of their approximations to clarified goals." 97

Yet just as an exclusive focus on transnational legal doctrine is insufficient from a governance-oriented perspective, so is an exclusive focus on law in action. To adopt the Holmesean equation of law with "[t]he prophecies of what the courts will do in fact",98 is to conflate what the governance-oriented approach wants to explain (the behavior of courts as global governors) with a potentially important explanatory variable (legal doctrine), making causal inference impossible. ${ }^{99}$ It also complicates the common conception of the rule of law as

prescriptive rule-formulations are the heavily operative factor in producing court decisions," while emphasizing that). Some political science approaches to the study of judicial behavior which have been criticized for their "almost pathological skepticism that law matters." Barry Friedman, Taking Law Seriously, 4 Perspectives on Politics 261, 262 (2006). See also Frank B. Cross, Political Science and the New Legal Realism: A Case of Unfortunate Interdisciplinary Ignorance, 92 Nw. U. L. Rev. 251 (making a similar argument). Although my approach is indeed skeptical insofar as it treats the extent and nature of the influence of legal rules on judicial decisionmaking as a question to be investigated empirically in various settings rather than something to be assumed, my approach takes seriously the role of transnational law in influencing the behavior of domestic courts as global governors, as explained below, infra, notes ___, and accompanying text. As Llewellyn himself emphasized, “'distrust' in this . . p point is not at all equivalent to 'negation in any given instance." Llewellyn, supra note _, at 1237.

${ }^{93}$ In this sense, the governance-oriented approach also has an affinity with the emerging "new legal realism." See Howard Erlanger, Bryant Garth, Jane Larson, Elizabeth Mertz, Victoria Nourse \& David Wilkins, Is It Time for a New Legal Realism? 2005 Wis. L. Rev. 335, 343 (2005) (noting that "[1] egal realism originally had a purely domestic focus, but now it is impossible for legal scholars to ignore transnational issues and arenas. One of the key tests of New Legal Realism will be its success in taking on major issues involved with the so-called 'globalization of law"').

${ }^{94}$ See supra, notes ___, and accompanying text.

${ }^{95}$ Cf. Rogers M. Smith, Political Jurisprudence: The "New Institutionalism," and the Future of Public Law, 82 Am. Pol. Sci. Rev. 89, 106 (“[r] esearch that identifies actual patterns in legal and political discourse and their consequences, testing their significance versus that of other structural contexts, should enable public law scholars to argue more powerfully about the values U.S. law has really embodied historically, about the way these values have shaped, and been shaped by, political conflicts, and about the results they have furthered or forestalled").

${ }^{96}$ William W. Fisher III, Morton J. Horwitz, \& Thomas A. Reed, American Legal Realism 52 (1993) (describing Llewellyn's contribution). See also Llewellyn, supra note _, at 1236-1237 (arguing for a "temporary divorce of Is and Ought for purposes of study" on the ground that "no judgment of what Ought to be done in the future with respect to any part of law can be intelligently made without knowing objectively, as far as possible, what that part of law is now doing").

${ }^{97}$ Myres S. McDougal, Some Basic Theoretical Concepts about International Law: A Policy-Oriented Framework of Inquiry, 4 J. Conflict Res. 337, 344 (1960).

98 Oliver Wendell Holmes, The Path of the Law, 10 Harv. L. Rev. _, (1897).

${ }^{99}$ Cf. Martha Finnemore \& Kathryn Sikkink, International Norm Dynamics and Political Change, 52 Int'1 Org. 887 , 892 (1998) ("'b]ecause one central question of norms research is the effect of norms on state behavior, it is important to operationalize a norm in a way that is distinct from the state or the nonstate behavior it is designed to explain"). 
including among its values judicial decisionmaking in accordance with recognized legal principles, a conception which becomes normatively incoherent if law and judicial decisionmaking are not kept analytically distinct. For these reasons, it is important to emphasize that the governance-oriented approach's emphasis on transnational law in action is a complement to, not a substitute for, doctrinal analysis.

\section{Focus on Broad Implications for Transnational Activity: Governance-Oriented Analysis as Complement to Litigant-Oriented Analysis}

Judicial decisionmaking in transnational litigation obviously has implications for the parties to a particular lawsuit, and for this reason litigant-oriented analysis is of self-evident importance. But to understand transnational judicial governance, it also is necessary to focus on the broader implications of domestic court decisionmaking for transnational activity, including the indirect effects discussed above. ${ }^{100}$ This focus may involve assessment of judicial decisionmaking in transnational litigation in terms of the values that one thinks should characterize systems of governance as a whole, such as the rule-of-law values I will use below to assess the allocation of adjudicative authority by U.S. district courts in context of the forum non conveniens doctrine. ${ }^{101}$ Alternatively, it may involve using methods of causal inference to test hypotheses about the effects of domestic law and domestic court decisionmaking on transnational activity, ${ }^{102}$ an approach that resonates with the legal realist "insistence on evaluation of any part of law in terms of its effects, and an insistence on the worthwhileness of trying to find these effects." 103

One implication of the governance-oriented approach's focus on the broad implications of domestic court decisionmaking on transnational activity is an effort to identify broad patterns of judicial decisionmaking in transnational litigation: judges affect society, and "[ $\mathrm{t}]$ hey do this mainly through the precedential force of their decisions, since a single decision rarely (not never) has a big impact." 104 A related implication is an emphasis on decisions that are published. The broad indirect effects of domestic court decisionmaking on transnational activity are largely due to the signals it transmits to transnational actors. ${ }^{105}$ Because publication is the principal mode of transmission, unpublished decisions are unlikely to have such effects. Publication, in other

\footnotetext{
${ }^{100}$ See supra, notes ___, and accompanying text.

${ }^{101}$ See infra Part III.

${ }^{102}$ For examples of research by comparative political economists that might provide a model for this type of governance-oriented analysis of transnational law, see supra, note _. Moreover, the relationship between transnational judicial governance and other systems of governance, discussed supra, notes _-_ and accompanying text, suggests that more dynamic analyses of how these systems interact may also be promising. See, e.g., Tim Büthe, Governance through Private Authority: Non-State Actors in World Politics, 58 J. Int'1 Affairs 281, 284 (2004) (arguing that global governance scholars should explore "the role of the state in [the] empowerment of private actors").

${ }^{103}$ Llewellyn, supra note _, at 1236-1237 (also noting the realist movement's "conception of the law as a means to social ends and not as an end in itself; so that any part needs constantly to be examined for its purpose, and for its effect, and to be judged in the light of both and of their relation to each other").

${ }^{104}$ Richard A. Posner, What Do Judges Maximize? (The Same Thing Everybody Else Does), 3 Sup. Ct. Econ. Rev. 1,18 (1993)

${ }^{105}$ See supra, notes ___, and accompanying text.
} 
words, is what gives domestic law its transnational shadow. ${ }^{106}$ Unpublished decisions are, of course, important to the litigants affected by those decisions. For this reason, and because of the importance of fairness and justice considerations in individual cases, the governance-oriented approach's focus on broad implications for transnational activity is a complement to, but not a substitute for, litigant-oriented analysis.

\section{Politics AND the RUle of LAW In TRANSNATIONAL JUdicial Governance: THE CASE OF ForUM NON CONVENIENS}

To illustrate the governance-oriented approach, I will apply it to the doctrine of forum non conveniens. ${ }^{107}$ This doctrine allows a domestic court to dismiss an action in favor of a foreign court on the ground that the foreign court is a more appropriate and convenient forum for adjudicating the controversy. ${ }^{108}$ Forum non conveniens is an interesting object of governanceoriented analysis for at least two reasons. First, it explicitly involves the allocation of governance authority among states - adjudicative authority, to be precise - which is one of the core functions of transnational judicial governance discussed above. ${ }^{109}$ By examining forum non

\footnotetext{
${ }^{106}$ Although theoretically motivated, the focus on published decisions - by which I mean not only decisions that are published in official reporters such as the Federal Supplement, but also those that are reported in widely accessible electronic databases such as LexisNexis or Westlaw-may, depending on the circumstances, make it difficult to generalize findings to the overall population of published and unpublished decisions. Whytock, Transnational Judicial Governance, supra note _, at 28-29. Cf. Susan M. Olson, Studying Federal District Courts Through Published Cases: A Research Note, 15 Justice System J. 782, 795 (1992) (generally critical of reliance on published decisions, but noting that such an approach "may be most justifiable for a researcher who is trying to study efficiently the 'public policy' output of district courts").

${ }^{107}$ I also am engaged in governance-oriented studies of other doctrinal fields of transnational litigation, including international choice of law, foreign sovereign immunity, and enforcement and recognition of foreign judgments, results of which should be available before the end of summer 2007.

${ }^{108}$ Sinochem International Co. Ltd. v. Malaysia International Shipping Corporation, 549 U.S. _, slip op. at 1 (2007). The Supreme Court's seminal statement of the modern doctrine of forum non conveniens is Gulf Oil Corp. v. Gilbert, 330 U.S. 501 (1947). The doctrine was clarified in Piper Aircraft Co. v. Reyno, 454 U.S. 235 (1981). For overviews of the doctrine, see Charles Alan Wright, Arthur R. Miller \& Edward H. Cooper, Federal Practice and Procedure: Jurisdiction 3d $\S 3828$ (2007), and Gary B. Born, International Civil Litigation in United States Courts: Commentary and Materials chap. 4 (3d ed. 1996).

${ }^{109}$ See Gilbert, 330 U.S. at 506-507 ("[i]n all cases in which the doctrine of forum non conveniens comes into play, it presupposes at least two forums in which the defendant is amenable to process; the doctrine furnishes criteria for choice between them"); Piper, 454 U.S. at 255 ("[a]t the outset of any forum non conveniens inquiry, the court must determine whether there exists an alternative forum"); and Sinochem, 549 U.S. slip op. at 1 (under the doctrine of forum non conveniens, "a federal court may dismiss an action on the ground that a court abroad is the more appropriate and convenient forum for adjudicating the controversy") and at 8 ("[a] forum non conveniens dismissal . . . is a determination that the merits should be adjudicated elsewhere"). See also Allan R. Stein, Forum Non Conveniens and the Redundancy of Court-Access Doctrine, 133 U. Penn. L. Rev. 781, 786 (describing forum non conveniens "as a means of allocating political authority"). Although courts often make forum non conveniens dismissal subject to the condition that the defendant submit to personal jurisdiction in the foreign forum, John Bies, Conditioning Forum Non Conveniens, 67 U. Chi. L. Rev. 489 (2000), there is evidence that most cases that are dismissed by U.S. district courts on forum non conveniens grounds are not in fact continued in the proposed foreign court. David W. Robertson, Forum Non Conveniens in America and England: "A Rather Fantastic Fiction," 103 L.Q. Rev. 398, 417-421 (1987). However, as Ralf Michaels argues, "this only suggests that the foreign forum is less attractive than the one where the suit was first brought; it does not suggest that multilateral considerations are not taken seriously.” Ralf Michaels, Two Paradigms of Jurisdiction, 27 Mich. J. Int'1 L. 1003, 1037 (2006). The limitations of the terms "allocation" and "deference," discussed supra at notes _-_, nevertheless merit reiteration in this context.
} 
conveniens decisionmaking in action, we may be able to develop a more certain understanding of how this allocative function of transnational judicial governance works in practice, and what legal and non-legal factors influence the choices judges make between the assertion of domestic governance authority and deference to foreign governance authority over transnational activity. Second, forum non conveniens offers an opportunity to examine the effectiveness of domestic courts in fostering transnational rule of law. ${ }^{110}$ By examining broad patterns of forum non conveniens decisionmaking, we may be able to shed some light on the compatibility of forum non conveniens practice with rule-of-law values such as predictability and impartiality. ${ }^{111}$ This part of the paper therefore focuses on descriptive and causal inference - that is, it seeks not only to describe how domestic courts behave as global governors in the forum non conveniens context, but also why they govern the way they do - and it uses these inferences as an empirical foundation for normatively evaluating transnational judicial governance according to rule-of-law values. The basis for these inferences is statistical and qualitative analysis of an original dataset of over 200 randomly selected published forum non conveniens decisions by United States District Court judges between 1990 and 2005. ${ }^{112}$

Before beginning the analysis, I must be explicit about the rule-of-law values that I will use to normatively evaluate the role of domestic courts in global governance, ${ }^{113}$ both of which I draw from the work of H.L.A. Hart: predictability and impartiality. ${ }^{114}$ By predictability, I mean

\footnotetext{
${ }^{110}$ Thus, the focus on forum non conveniens allows me to explicitly address the topic of the panel for which this paper was prepared, namely "the development and effectiveness of different institutions in fostering the international 'rule of law." I prefer the term "transnational" rule of law, to emphasize that nonstate actors as well as states are active participants.

${ }^{111}$ A third reason is that forum non conveniens is a quantitatively important form of transnational judicial governance decisionmaking. I estimate that U.S. district courts have published at least 691 transnational forum non conveniens decisions between 1990 and 2006, with 95 percent certainty that the actual number is between 613 and 775. Whytock, supra note _, at 15. See also Martin Davies, Time to Change the Federal Forum Non Conveniens Analysis, 77 Tul. L. Rev. 309, 311 (2002) (“"[e]very year, federal courts consider hundreds of motions for forum non conveniens dismissal").

112 See Whytock, supra note _, at 17-18, for details about how the dataset was developed, and at 28-29, for the reasons for focusing on published cases (defined as those published in official reporters or available in the LexisNexis database) as well as the threats to inference that this focus may entail.

113 The proper meaning of "rule of law" is debated, and I will make no effort here to contribute to that debate. See Erik G. Jensen, The Rule of Law and Judicial Reform: The Political Economy of Diverse Institutional Patterns and Reformers' Responses, in Beyond Common Knowledge: Empirical Approaches to the Rule of Law 336,338 (Erick G. Jensen \& Thomas C. Heller eds., 2003) (briefly summarizing the debate).

${ }^{114}$ H.L.A. Hart, The Concept of Law (2d ed. 1994). Cf. Stephen Holmes, Lineages of the Rule of Law, in Democracy and the Rule of Law 19 (José Maria Maravall \& Adam Przeworski eds., 2003) (emphasizing "two features of the rule of law as commonly understood: predictability and equality"). These values are shared by rule of law concepts that insist that "laws have become widely known and understood, and where they are applied equally to everyone." Jensen, supra note _, at 338. The values of predictability and impartiality imply a functional rather than a substantive conception of the rule of law. By functional, I mean what Martin Shapiro labels a "primitive" notion of the rule of law which "requires only that the state's preferences be achieved by general rules rather than by discretionary - arbitrary-treatment of individuals," but "[ $\mathrm{t}]$ here is not even a hint in this concept that the law is neutral as between the citizens or independent of the will of the state." Martin Shapiro, The Success of Judicial Review and Democracy, in On Law, Politics, and Judicialization 149, 166 (eds. Martin Shapiro \& Alec Stone Sweet, 2002). By substantive notions of the rule of law, I mean those that equate the rule of law with "the rule of norms that are just and true in some universal sense and thus of laws that are neutral and independent in relation to the particular immediate preference of the government. Then the rule of law comes to forbid not only arbitrary state behavior directed against particular individuals but bad state behavior even when the behavior is in
} 
the degree of certainty transnational actors have about the rules that will be applied to govern their behavior. Thus, in an ideal rule-of-law system, there must be "a rule for conclusive identification of the primary rules of obligation." 115 Moreover, rules "must be intelligible and within the capacity of most to obey, and in general they must not be retrospective."116 Courts play a particularly important role in fostering predictability; yet the use of court decisions "as authoritative guides to the rules depends on a somewhat shaky inference from particular decisions, and the reliability of this must fluctuate both with the skill of the interpreter and the consistency of the judges." 117 By impartiality, I mean "the notion that what is to be applied to a multiplicity of different persons is the same general rule, undeflected by prejudice, interest, or caprice."118 Impartiality thus implies not only equal treatment under the law, but also that courts must allocate values according to recognized legal rules - including, in the case of transnational judicial governance, domestic rules of transnational law - not according to political or other extra-legal criteria. ${ }^{119}$

\section{Rule of Law Outcomes? Patterns of Forum Non Conveniens Decisionmaking}

The governance-oriented approach calls for an understanding of forum non conveniens in action. In particular, how do U.S. district court judges actually apply the doctrine to transnational actors? Without such an understanding, normative criticism is limited to what the doctrine says. The governance-oriented approach uses basic methods of descriptive inference to

the form of rules." Id. On the functional/substantive distinction, see Matthew Stephenson, Rule of Law as a Goal of Development Policy, World Bank, available at http://go.worldbank.org/SK9CKPG830.

${ }^{115}$ Hart, supra note _, at 95. Because they determine which state's laws apply to transnational activity, the principles of international choice of law play an extraordinarily important role in fostering this rule-of-law value in transnational relations, a role which I am exploring in related research.

${ }^{116}$ Id. at 207. As Stephen Holmes notes, discussing Machiavelli's conception of the rule of law, "[c]itizens become attached to a rule-of-law regime . . . because it makes it possible for them to predict the consequences of their actions, to pursue remedy when wronged, and generally to plan their lives." Stephen Holmes, Lineages of the Rule of Law, in Democracy and the Rule of Law 19, 21 and 32 (José Maria Maravall \& Adam Przeworski eds., 2003) (noting that Machiavelli's conception is incomplete "because it focuses only on legal certainty as the offspring of regularized constraints on state power" whereas "[w]e ordinarily associate the rule of law not only with predictability but also with a roughly equal treatment of social groups").

${ }_{117}^{11}$ Hart, supra note _, at 97.

${ }^{118}$ Id. at 206. This is a functional rather than a substantive rule-of-law value, as Hart emphasizes: "though the most odious laws may be justly applied, we have, in the bare notion of applying a general rule of law, the germ at least of justice." Id.

${ }^{119}$ See Jensen, supra note _, at 338 (noting that some rule of law concepts attach special importance to legal limitations on the scope of legitimate state action). Arbitrariness and unfettered discretion in judicial decisionmaking is inconsistent with both of these values: with predictability, because it generates uncertainty, and impartiality, because it implies that factors other than publicly recognized primary rules are influencing the allocation of values. As Ronald Dworkin puts it, "the most abstract and fundamental point of legal practice is to guide and constrain the power of government in the following way. Law insists that force not be used or withheld, no matter how useful that would be to ends in view, no matter how beneficial or noble these ends, except as licensed or required by individual rights and responsibilities flowing from past political decisions about when collective force is justified. The law of a community on this account is the scheme of rights and responsibilities that meet that complex standard: they license coercion because they flow from past decisions of the right sort. They are therefore 'legal' rights and responsibilities. This characterization of the concept of law sets out, in suitably airy form, what is sometimes called the 'rule' of law." Ronald Dworkin, Law's Empire 93 (1986). It should be noted, however, that discretion may serve other important values, such as fairness, even if it is not easily squared with functional understandings of the rule of law. 
provide the empirical foundations necessary to extend normative analysis to what courts actually do in the forum non conveniens context and, more precisely, to explore the extent to which forum non conveniens decisionmaking conforms to the rule-of-law values of predictability and impartiality.

Forum Non Conveniens Dismissal Rates and Transnational Rule of Law. In Gulf Oil v. Gilbert (1947), the U.S. Supreme Court emphasized that "the plaintiff's choice of forum should rarely be disturbed" under the forum non conveniens doctrine. ${ }^{120}$ In practice, however, dismissal on forum non conveniens grounds is not rare at all. U.S. district courts grant the motions, thus deferring to foreign adjudicative authority, approximately 47 percent of the time in published decisions between 1990 and 2005 (see Table 1 below). ${ }^{121}$ Beyond being bad news for plaintiffs, ${ }^{122}$ this has mixed implications for the transnational rule of law. On the one hand, the evidence raises questions about whether forum non conveniens in action, which results in frequent dismissals, is inconsistent with forum non conveniens doctrine, which says dismissal should be rare, contrary to the rule-of-law values of predictability and impartiality. One cannot, however, attribute too much legal meaning to this apparent disparity between practice and doctrine without understanding potential case selection effects. ${ }^{123}$ Although it is possible that the high dismissal rate indicates unfaithful application of Supreme Court precedents, an alternative explanation might be that plaintiffs simply file a disproportionate number of transnational suits in U.S. courts under factual circumstances that genuinely merit dismissal under the doctrine. ${ }^{124}$

On the other hand, the 47 percent estimate might be interpreted as good news for the transnational rule of law. Regardless of case selection effects, it indicates clearly that U.S. district courts are willing to defer to foreign adjudicative authority, and to do so frequently; ${ }^{125}$ and it suggests that, at a minimum, claims about the parochialism of American private international law doctrine ${ }^{126}$ may deserve qualification. The dismissal rate might even be

\footnotetext{
${ }^{120} 330$ Gilbert, U.S. at 508. See also [] (all emphasizing the high standard that a defendant must meet to succeed on a forum non conveniens motion).

${ }^{121}$ I estimate the dismissal rate at 47 percent, with 95 percent certainty, using an Agresti-Coull confidence interval, that the actual rate is between 41 and 54 percent. It is important to note that because my dataset includes only published decisions (including those published in the Federal Supplement or in widely available electronic databases such as NexisLexis and Westlaw), generalizing any of the descriptive inferences in this paper to the overall population of forum non conveniens decisions may entail substantially lower levels of certainty.

${ }^{122}$ The Supreme Court in Piper, 454 U.S. at 252, explicitly stated that one rationale for the forum non conveniens doctrine is to discourage forum shopping by plaintiffs.

${ }^{123}$ For a very useful discussion of selection effects, see Kevin M. Clermont \& Theodore Eisenberg, Litigation Realities, 88 Cornell L. Rev. 119 (2002). Early work on selection effects, criticized by Clermont \& Eisenberg, actually implies that win rates generally should approximate 50 percent. [Priest \& Klein] In addition, it is possible that the dismissal rate is substantially lower in unpublished cases, which would not be altogether surprising if one assumes that judges feel a particularly important need to publicly justify dismissals. However, a Pearson chisquared test of independence does not support this hypothesis: It indicates that we cannot reject the null hypothesis that there is no association between dismissal and whether or not a U.S. district court forum non conveniens decision is published in the Federal Reporter $(\mathrm{p}=.655)$.

${ }^{124}$ See Gilbert, 330 U.S. at 508 (clarifying that dismissal should be rare "unless the balance is strongly in favor of the defendant").

${ }^{125}$ My data suggests that U.S. district courts have deferred to foreign adjudicative authority in the forum non conveniens context at least 350 times between 1990 and 2005. Whytock, supra note _, at 15 .

${ }^{126}$ See, e.g., ("')).
} 
interpreted as circumstantial evidence of an emerging "global community of courts"127 characterized by "the awareness of judges in every country and at every level of participation in a common judicial enterprise," "28 a notion of judicial comity according to which "courts in different nations are entitled to their fair share of disputes," 129 and decisions to "defer to or reject their foreign counterparts" for reasons other than "sovereign prerogatives."130 But Table 2 also suggests that the likelihood of deference to foreign adjudicative authority is on a declineperhaps due to changes in the partisan composition of the U.S. government or the post 9/11 political climate. ${ }^{131}$ Like other forms of cooperation, the global community of courts - or at least participation in it by U.S. courts on the basis of judicial comity - may be influenced by the ebbs and flows of domestic politics. ${ }^{132}$

\section{Table 1: Forum Non Conveniens Dismissal Rates, Published U.S. District Court Decisions, 1990-2005}

\begin{tabular}{lcccc}
\hline & Overall & $1990-1994$ & $1995-1999$ & $2000-2005$ \\
\hline Number of Decisions & 210 & 62 & 60 & 88 \\
Estimated Dismissal Rate & 47.1 & 61.3 & 45.0 & 38.6 \\
$95 \%$ Confidence Interval & $40.5,53.9$ & $48.8,72.4$ & $33.1,57.5$ & $29.1,49.1$
\end{tabular}

Notes: There is $95 \%$ certainty that the actual dismissal rate in the overall population of published U.S. district court forum non conveniens decisions is between the two values indicated in the "95\% Confidence Interval" row. Agresti-Coull 95\% confidence interval reported. A Pearson chi-squared test of independence indicates that we can reject with more than $95 \%$ confidence the null hypothesis that there is no association between dismissal and the three time periods $(\mathrm{p}=.022)$.

Finally, the forum non conveniens doctrine sends mixed signals about the likelihood of dismissal, which reduces the rule-of-law value of predictability, and increases the ambiguity of the doctrine's forum shopping implications. On the one hand, the Supreme Court, as just noted, has emphasized that dismissal should be rare and that substantial deference is owed to the plaintiff's choice of forum. ${ }^{133}$ On the other hand, the Supreme Court has stated that the

\footnotetext{
${ }^{127}$ Slaughter, New World Order, supra note _, at 100.

${ }^{128}$ Id. at 102 .

${ }^{129}$ Id. at 87.

${ }^{130}$ Id. at 91.

${ }^{131}$ During 1990-1994, both houses of Congress were Democratic and in 1993 and 1994 the president was also Democratic (overall, a Democratic political environment); in 1995-1999, both houses of Congress were Republican and the president was Democratic (split political environment); and in most of the 2000-2005, both houses of Congress were Republican and the president was Republican (overall, a Republican political environment. Strategic theories of judicial decisionmaking would expect the political environment to have such an impact, but in a statistical analysis that controlled for other factors, I did not find strong empirical support for this proposition. This trend is even more interesting in light of the simultaneous increase in caseload, which one might expect to increase the likelihood of dismissal as a docket management tool. See Whytock, supra note _, at 20.

${ }^{132}$ This proposition is consistent with liberal international relations theory, upon which Slaughter's liberal theory of international law is based. See Andrew Moravcsik, Taking Preferences Seriously: A Liberal Theory of International Politics, 51 Int'l Org. 513 (1997).

${ }^{133}$ Gilbert, 330 U.S. at 508.
} 
deference owed to foreign plaintiffs is lower, and justified this proposition as a tool for discouraging forum shopping. ${ }^{134}$ For his part, Justice Scalia has expressed doubt that the forum non conveniens doctrine can affect plaintiffs' choice of forum at all given its discretionary nature. ${ }^{135}$ However, with a dismissal rate of nearly 50 percent, forum non conveniens in action sends a clear signal that dismissal is very likely indeed, a signal that might be more likely than the ambiguous doctrinal signal to affect choice of forum by transnational actors. ${ }^{136}$

Domestic and Foreign Parties in Forum Non Conveniens Doctrine and Practice. The rule-of-law value of impartiality implies both that U.S. district courts should accord equal treatment to domestic and foreign parties, and that they should base their decisions on recognized legal doctrine. In the forum non conveniens context, this creates a paradox, because the doctrine itself favors domestic parties. In Piper Aircraft v. Reyno (1981), the Supreme Court held that plaintiffs who are "[c]itizens or residents deserve somewhat more deference than foreign plaintiffs" with respect to their choice of forum. ${ }^{137}$ With an estimated rate of dismissal when the plaintiffs are foreign that is twice as high as when there is at least one domestic plaintiff (see Table 2 below), one might suspect that forum non conveniens in action goes beyond giving domestic plaintiffs merely "somewhat more" deference. ${ }^{138}$

However, there appears to be no such disparate treatment of domestic and foreign defendants. ${ }^{139}$ The evidence therefore does not suggest a general bias in favor of U.S. parties. Rather, impartiality between domestic and foreign parties only appears to fail when partiality is required by the forum non conveniens doctrine itself. One way to resolve the rule of law paradox conceptually might be to distinguish internal and external rule of law perspectives on transnational judicial governance. From an internal perspective, the fact of (if not the full extent of) domestic party bias in forum non conveniens decisionmaking is consistent with the impartial application of recognized domestic legal doctrine. From an external perspective, the outcome is discrimination against foreign parties, which is not an outcome that is necessarily consistent with foreign and international sources of transnational law, and thus not easily reconciled with the value of impartiality.

\footnotetext{
${ }^{134}$ Reyno, 454 U.S. at 256 and 251-252. This signal is highly ambiguous in and of itself. As Martin Davies [] argues, the court's holding that "[c]itizens or residents deserve somewhat more deference than foreign plaintiffs" begs the question of how much more weight.

${ }^{135}$ American Dredging Co. v. Miller, 510 U.S. 443, 455 (1994) ("to tell the truth, forum non conveniens cannot really be relied upon in making decisions about secondary conduct - in deciding, for example, where to sue or where one is subject to being sued").

${ }^{136}$ That said, neither forum non conveniens doctrine nor forum non conveniens in action necessarily gives transnational actors much certainty about the circumstances in which suits are likely to be dismissed, which is problematic from the perspective of the rule-of-law value of predictability. This is a question I will return to below. ${ }_{137}^{137} 454$ U.S. at 256.

${ }^{138}$ The presence of a domestic plaintiff reduces the probability of dismissal by 20 percent, even after controlling for other factors. Whytock, supra note _, at 23. There is 95 percent certainty that the actual reduction is between 9 and 36 percent.

${ }^{139}$ The $95 \%$ confidence intervals for rate of dismissal when there is a domestic defendant and when defendants are all foreign overlap substantially ([40.7, 60.3] and [35.6, 53.9], respectively), and a Pearson chi-squared test of independence indicates that we cannot reject the null hypothesis that there is no association between dismissal and the presence of a domestic defendant $(\mathrm{p}=.391)$. See also Whytock, supra note _, at 21 (finding that the nationality of the defendant does not have a statistically significant effect on forum non conveniens decisionmaking in U.S. district courts).
} 


\section{Table 2: Forum Non Conveniens Dismissal Rates for Domestic and Foreign Plaintiffs}

\begin{tabular}{lccc}
\hline & $\begin{array}{c}\text { Number of } \\
\text { Decisions }\end{array}$ & $\begin{array}{c}\text { Estimated Dismissal } \\
\text { Rate }(\%)\end{array}$ & $\begin{array}{c}95 \% \text { Confidence } \\
\text { Interval }\end{array}$ \\
\hline Domestic Plaintiff & 101 & 31.1 & {$[23.1,40.5]$} \\
Foreign Plaintiff & 106 & 63.4 & {$[53.6,72.1]$} \\
\hline Total & 207 & 46.9 & {$[40.2,53.7]$} \\
\hline
\end{tabular}

Notes: There is $95 \%$ certainty that the actual dismissal rate in the overall population of published U.S. district court forum non conveniens decisions is between the two values indicated in the "95\% Confidence Interval" column. Agresti-Coull 95\% confidence interval reported. Domestic Plaintiff means at least one plaintiff is foreign. Foreign Plaintiff means all plaintiffs are foreign. A Pearson chi-squared test of independence indicates that we can reject with more than $99 \%$ confidence the null hypothesis that there is no association between dismissal and the presence of a domestic plaintiff $(\mathrm{p}=.000)$.

Some critics have posited that there is a more targeted form of domestic party bias in forum non conveniens decisionmaking that is not warranted by doctrine, namely a bias in favor of U.S. corporate defendants that protects them from liability for harm caused by their foreign activity to foreign individuals. ${ }^{140}$ There are, in fact, a priori theoretical grounds to expect judicial decisionmaking outcomes in transnational litigation to favor corporate parties, based on the seminal work of law and society scholar Marc Galanter on why repeat players in litigation tend to be more successful than other parties in the U.S. legal system. ${ }^{141}$ The evidence does not support this conclusion: there is not a statistically significant association between a foreign individual suing a U.S. business for an injury to that individual outside the United States on the one hand, and forum non conveniens dismissal on the other hand. ${ }^{142}$ Nor does there appear to be a more general bias in favor of business plaintiffs or business defendants. ${ }^{143}$

\footnotetext{
${ }^{140}$ See, e.g., Paul, supra note _, at 170 (concluding, after discussion of the Bhopal litigation, that "the application of forum non conveniens insulates United States companies manufacturing abroad from strict United States regulatory standards"). [others]

${ }^{141}$ According to Galanter, repeat players in litigation, particularly those with greater access to experienced lawyers and other litigation resources, are likely to be more successful in litigation than others. Marc Galanter, Why the "Haves" Come out Ahead: Speculations on the Limits of Legal Change, 9 Law \& Soc'y. Rev. 95 (1974). In transnational litigation, businesses are more likely than individuals to be just this type of repeat player.

${ }^{142}$ The $95 \%$ confidence intervals for dismissal when there is not and when there is foreign individual suing a U.S. business for an injury to that individual outside the United States overlap substantially ([38.6, 52.6] and [40.9, 81.0], respectively), and a Pearson chi-squared test of independence indicates that we cannot reject the null hypothesis that there is no association between dismissal and this particular configuration of litigation $(\mathrm{p}=.143)$.

${ }^{143}$ The $95 \%$ confidence intervals for dismissal when there is not and when there is a business plaintiff overlap substantially $([37.2,55.7]$ and $[38.6,57.6]$, respectively), and a Pearson chi-squared test of independence indicates that we cannot reject the null hypothesis that there is no association between dismissal and the presence of a business plaintiff $(\mathrm{p}=.800)$. Likewise, the $95 \%$ confidence intervals for dismissal when there is not and when there is a business defendant overlap substantially ([25.6, 63.2] and [40.6, 54.7], respectively), and a Pearson chi-squared test of independence indicates that we cannot reject the null hypothesis that there is no association between dismissal and the presence of a business defendant $(\mathrm{p}=.709)$.
} 
Adequacy of Foreign Courts in Forum Non Conveniens Dismissals. To the extent that the forum non conveniens doctrine results in the dismissal of cases in favor of foreign courts that do not operate on the basis of the rule of law, this would be bad news for transnational rule of law. After all, even if the decision to defer to a foreign court is predictable and impartial, if the result is that a plaintiff is faced with the prospect of litigating in a legal system that is either unpredictable or partial, the result cannot be said to square with rule of law values. Unfortunately, the forum non conveniens doctrine does little to protect defendants against such dismissals. ${ }^{144}$ In Piper v. Reyno, the Supreme Court noted that "[a]t the outset of any forum non conveniens inquiry, the court must determine whether there exists an alternative forum," but added that "[o]rdinarily, this requirement will be satisfied when the defendant is "amendable to process" in the other jurisdiction." 145 Only in "rare circumstances ... where the remedy offered by the other forum is clearly unsatisfactory, the other forum may not be an adequate alternative, and the initial requirement may not be satisfied. Thus, for example, dismissal would not be appropriate where the alternative forum does not permit litigation of the subject matter of the dispute." 146

In practice, however, it appears that forum non conveniens dismissals are rarely made in favor of foreign states that have worse-than-average rule of law ratings. Table 3 below presents two different measures of domestic rule of law for the foreign states to which U.S. district courts in my sample considered deferring: the "Rule of Law" indicator from the World Bank's Governance Indicators, and the "Civil Liberties" rating from the Freedom House Freedom in the World report, which includes a rule-of-law component. ${ }^{147}$ As Table 3 below indicates, the average rule of law rating for foreign states to which U.S. district courts defer in forum non conveniens decisions is substantially better than the world average. ${ }^{148}$ It also is higher than the average for courts to which U.S. district courts decided not to defer. ${ }^{149}$

\footnotetext{
${ }^{144}$ Based on evidence suggesting that most cases dismissed on forum non conveniens grounds are not continued in a foreign court at all [cites to Robertson, etc.], one might argue that this issue is moot. On the other hand, it is conceivable that dismissals in favor of non-rule-of-law courts may in fact be one reason why such cases are not continued. Moreover, it is probable that such dismissals may enhance the bargaining position of defendants to an even greater extent than dismissals to well functioning legal systems that operate in accordance with core rule-oflaw values.

${ }^{145}$ Piper, 454 U.S. at 255.

${ }^{146} \mathrm{Id}$.

${ }^{147}$ Because the Freedom House rating includes components other than the rule of law, it is a less precise measure.

${ }^{148}$ The average for courts to which forum non conveniens dismissals are made (1.03 using the World Bank indicator and 2.10 using the Freedom House rating) falls within the best 25 percent of countries worldwide (squarely so using the World Bank indicator, and approximately so using the Freedom House rating).

${ }^{149}$ This difference is not, however, statistically significant at conventional levels. Moreover, it is important to remember that the averages do not mean that U.S. district courts never dismiss in favor of foreign courts with worse than average rule-of-law ratings, as indicated by the ranges in the value of those ratings for dismissals.
} 


\section{Table 3: Rule of Law Ratings of Foreign States to Which U.S. District Courts Defer in Forum Non Conveniens Decisions}

\begin{tabular}{lcc}
\hline & $\begin{array}{c}\text { World Bank } \\
\text { Rule of Law Indicator } \\
\text { (Higher is Better) }\end{array}$ & $\begin{array}{c}\text { Freedom House } \\
\text { Civil Liberties Rating } \\
\text { (Lower is Better) }\end{array}$ \\
\hline Mean (Dismissed) & 1.03 & 2.10 \\
\hline Mean (Not Dismissed) & -.99 to 2.07 & 1 to 6 \\
Range (Not Dismissed) & .92 & 2.40 \\
\hline Mean (Overall Sample) & -1.46 to 2.14 & 2.26 \\
Range (Overall Sample) & .97 & 1 to 7 \\
\hline Mean (World in 2000) & -1.46 to 2.14 & 1 to 7 \\
Range (World in 2000) & -.09 & 2 to 5 \\
$25^{\text {th }}$ to $75^{\text {th }}$ Percentile (World in 2000) & -2.11 to 2.37 & 192 countries \\
Number of Observations & -.80 to .54 & \\
\hline
\end{tabular}

Notes: (1) The World Bank Rule of Law Indicator is designed to measure "the extent to which agents have confidence in and abide by the rules of society, and in particular the quality of contract enforcement, the police, and the courts, as well as the likelihood of crime and violence." Daniel Kaufmann, Aart Kraay \& Massimo Mastruzzi, Governance Matters V: Aggregate and Individual Governance Indicators for 1996-2005 4 (Sept. 2006) (available http://www.worldbank.org/wbi/governance). (2) Freedom House explains its Civil Liberties Rating as follows: "Countries and territories that receive a rating of 1 come closest to ensuring the freedoms expressed in the civil liberties checklist, including freedom of expression, assembly, association, education, and religion. They are distinguished by an established and generally equitable system of rule of law. Countries and territories with this rating enjoy free economic activity and tend to strive for equality of opportunity." Freedom House, Freedom in the World: Methodology (2006) (available at http://www.freedomhouse.org). The general rule of law items on the civil liberties checklist include the following: (a) "Is there an independent judiciary?" (b) "Does the rule of law prevail in civil and criminal matters? Are police under direct civilian control?" (c) "Is there protection from political terror, unjustified imprisonment, exile, or torture, whether by groups that support or oppose the system? Is there freedom from war and insurgencies?" and (d) "Do laws, policies, and practices guarantee equal treatment of various segments of the population?" Id.

However, neither the forum non conveniens doctrine nor U.S. district court decisionmaking necessarily should be credited for this relatively positive state of affairs. A comparison of the mean rule of law ratings for the overall sample of forum non conveniens decisions and for the world indicates that the former is substantially better than the latter. This suggests that non-rule-of-law countries are for the most part being selected out through a case- 
selection process rather than through the forum non conveniens decisionmaking process. ${ }^{150}$ Although the data allows little more than speculation about the reason for this, one explanation, based on earlier interpretations of liberal international law theory, might be that there is indeed a distinct "liberal zone of law" — a "zone of liberal states in which the laws governing transnational disputes are domestic laws applied by domestic courts guided by pluralist principles"-whereas transnational disputes involving liberal and nonliberal states are more likely to be resolved through political processes. ${ }^{151}$ If this is correct, then the scope of transnational judicial governance, and the ability of domestic law and domestic courts to foster transnational rule of law, may be limited to transnational relations among liberal democracies or, more specifically, to states that have relatively well-functioning domestic rule of law systems.

Better-than-average rule of law in the foreign state may be desirable, but it is not sufficient for transnational rule of law. Another important indicator of the extent to which domestic courts foster the transnational rule of law is how seriously they engage in analysis of the proposed foreign court. The evidence is not encouraging. In Reyno, the Supreme Court identified two aspects of this analysis: availability and adequacy. ${ }^{152}$ To be available, the defendant must be amenable to process in the foreign court, and to be adequate the remedy offered by the foreign court must not be "clearly unsatisfactory." 153 However, in an estimated 19 percent of forum non conveniens dismissals, the court engaged in no alternative forum analysis. ${ }^{154}$ One way to increase the likelihood that the defendant will be amenable to process and that the proposed foreign court will indeed be available is to condition the forum non conveniens dismissal on the defendant's waiver of jurisdictional defenses. ${ }^{155}$ But U.S. district courts impose such conditions only in an estimated 42 percent of forum non conveniens dismissals. ${ }^{156}$ And to determine whether or not the legal remedy offered in the foreign court is "clearly unsatisfactory," the U.S. district court must engage in at least a minimal choice of law analysis to determine whether the foreign court would apply U.S. law and, if not, a comparative analysis to determine whether the law that the foreign court will apply offers a satisfactory

\footnotetext{
${ }^{150}$ In fact, plaintiffs rarely challenge the capacity or the integrity of foreign courts in the forum non conveniens context. In only 13 of the 210 cases in my random sample (6 percent) did plaintiffs challenge on the ground of capacity (and in only 3 of these did the court agree), and in only 17 of the 210 cases in my random sample (8 percent) did plaintiffs challenge on the ground of integrity (and in only 4 of these cases did the court agree).

${ }^{151}$ Anne-Marie Burley, Law among Liberal States: Liberal Internationalism and the Act of State Doctrine, 92 Colum. L. Rev. 1907, 1917-1921 (1992). See also Anne-Marie Slaughter, A Liberal Theory of International Law, 94 Am. Soc'y Int'1 L. Proc. 240, 249 ("I do subscribe to a distinction between liberal and non-liberal states as a positive indicator of how states are likely to behave in a variety of circumstances, including within or toward international institutions"). For a critique of this claim, see José E. Alvarez, Do Liberal States Behave Better? A Critique of Slaughter's Liberal Theory, 12 Eur. J. Int'1 L. 183 (2001). Another possibility is that transnational actors based in non-rule of law countries are less likely to prefer litigation as a form of dispute resolution, due to disillusionment from their home country experience.

${ }^{152}$ Piper, 454 U.S. at 255.

${ }^{153} \mathrm{Id}$.

${ }^{154}$ There is 95 percent certainty that the actual percentage in the overall population of published forum non conveniens dismissals is between 12.6 and 28.1. In many of these cases, however, the lack of analysis may be due to a lack of objection to the proposed foreign court on the part of the plaintiff.

${ }^{155}$ Martin Davies, Time to Change the Federal Forum Non Conveniens Analysis, 77 Tul. L. Rev. 310, $317-319$ (2002). Occasionally, other conditions are added as well, including willingness of the foreign court to hear the case. Id. at 317.

${ }^{156}$ There is 95 percent certainty that the actual percentage in the overall population of published forum non conveniens dismissals is between 33.5 and 52.3 .
} 
remedy. ${ }^{157}$ Yet I estimate that U.S. district courts engage in choice of law analysis in only 10 percent, ${ }^{158}$ and comparative law analysis in only 18 percent, ${ }^{159}$ of forum non conveniens dismissals. Under these circumstances, it is difficult to see how U.S. district court judges - not to mention plaintiffs - can have very much confidence in these adequacy determinations. United States district courts could more effectively foster transnational rule of law by performing the alternative forum analysis mandated by the Supreme Court in a more rigorous manner. ${ }^{160}$

\section{Rule of Law Determinants? The Law and Politics of Forum Non Conveniens Decisionmaking}

We now have a basic understanding of how domestic courts behave as global governors in the forum non conveniens context. Using basic statistical techniques of descriptive inference, we have explored some of the global governance implications of forum non conveniens in action, normatively evaluating them against the rule of law values of predictability and impartiality. But what can we learn about the causes of these decisions? Why do domestic courts govern the way they do? More precisely, what factors influence the fundamental transnational judicial governance decision between the assertion of domestic authority and deference to foreign authority to govern transnational activity? And are these factors predominantly political or legal in character? In this section, I will summarize work that I have done elsewhere in an effort to shed light on these questions. ${ }^{161}$ The focal points of my discussion will be seven hypotheses about political and rule-of-law determinants of judicial allocation of governance authority over transnational activity, derived from theories of judicial decisionmaking and international relations, and Table 4 below, which presents the results of a statistical test of the hypotheses using the forum non conveniens dataset described above. ${ }^{162}$ The resulting causal inferences will provide another empirical basis for normatively evaluating transnational judicial governance, and allow us to further explore the extent to which domestic law and domestic courts effectively foster transnational rule of law.

\footnotetext{
${ }^{157}$ It is hard to see how the adequacy analysis could be conclusive, or even suggestive, absent the choice of law analysis and, depending on the outcome of that analysis, a comparative law analysis. See Davies, supra note _, at 320-321 (agreeing that the Supreme Court's statement of the forum non conveniens doctrine in Gilbert and Reyno logically requires choice of law analysis, while noting that this requirement goes against one of the motivations of the doctrine, which is to reduce the administrative burden placed on U.S. district courts).

${ }^{158}$ There is 95 percent certainty that the actual percentage in the overall population of published forum non conveniens dismissals is between 5.4 and 17.8 .

${ }^{159}$ There is 95 percent certainty that the actual percentage in the overall population of published forum non conveniens dismissals is between 11.7 and 27.0.

${ }^{160}$ Given how busy district court judges are, this simply might not be practicable. See infra, notes _-_, and accompanying text. In any event, this would only be a first step. I would argue that the doctrinal guidelines for adequate alternative forum analysis are themselves in need of improvement to give plaintiffs whose suits are dismissed in favor of a foreign court protections vis-à-vis that court that are equivalent to the protections that U.S. personal jurisdiction doctrine gives defendants vis-à-vis U.S. courts.

${ }^{161}$ Christopher A. Whytock, Politics and the Rule of Law in Transnational Judicial Governance: The Case of Forum Non Conveniens (Feb. 2007) (unpublished manuscript, available at http://ssrn.com/abstract=969033) [hereinafter Transnational Judicial Governance].

${ }^{162}$ This section provides only a brief overview of the hypotheses, methods, and findings. Readers interested in more information on the theoretical bases for these hypotheses and about the data and research design are urged to consult Whytock, Transnational Judicial Governance, supra note _.
} 
Political Factors Influencing Transnational Judicial Governance. The first five hypotheses suggest that transnational judicial governance is influenced by political factors:

- Attitudinal Model Hypothesis (H1): A Republican judge is less likely to grant a forum non conveniens motion (thus deferring to foreign adjudicative authority) than a Democratic judge. According to the leading theory of judicial decisionmaking, the "attitudinal model," court decisions are based on judges" personal policy preferences ${ }^{163}$ often measured in terms of partisan affiliation, with Republican indicating conservative attitudes and Democratic indicating liberal attitudes. ${ }^{164}$ In other words, "Justice William J. Brennan, Jr., decided cases as he did because he was liberal; Justice William Rehnquist or Warren Burger, because they were conservative." ${ }^{\prime 65}$ Survey data suggests that, on average, Republicans more strongly and unconditionally favor assertion of domestic authority over transnational activity than Democrats. ${ }^{166}$ It is therefore plausible that Republican judges are less likely to defer to foreign governance authority (including deference to foreign adjudicative authority on forum non conveniens grounds) than Democratic judges. ${ }^{167}$

- Strategic Model Hypothesis (H2): A judge is less likely to grant a forum non conveniens motion in a Republican political environment than a Democratic political environment. Another leading theory of judicial decisionmaking, the "strategic model," shares the attitudinal model's basic assumption that judges are policy seekers, but emphasizes the constraints that they face. To maximize their preferences, justices must act strategically; that is, they must consider not only their own preferences, but also the preferences and actions of other political actors such as Congress and the president, who have a "vast array of powers over matters important to the Court."

${ }^{163}$ (Rohde and Spaeth 1976; Spaeth 1995; Segal and Spaeth 2002)

${ }^{164}$ The use of party affiliation as a measure for a judge's ideology follows George and Epstein $(1992,328)$ and George (1998, 1651-1652). To create the variable, I began by using the political party of the nominating president as a proxy for the judge's political party, again following George and Epstein $(1992,328)$ and George $(1998,1651$ 1652), using data from the Federal Judicial Center's Biographical Directory of Federal Judges available at http://www.fjc.gov/public/home.nsf/hisj. I then made corrections when Martinek's (2005) Lower Federal Court Confirmation Database contained data on a judge's personal partisan identification that was different from that of the nominating president, which was the case for 18 observations in my dataset.

165 (Spaeth 1995, 305)

${ }^{166}$ Of most direct relevance, Republicans overall were more likely than Democrats to agree that the United States should follow its own national interests even when its allies strongly disagree, and less likely than Democrats to agree that U.S. foreign policy should take into account the interests and views of allies Pew Research Center for the People and the Press (2005a, 21), which is consistent with the assumption that conservatives are less likely to defer to foreign governance authority. However, only the most ideologically driven groups within each party expressed views that differ significantly from the national average $(2005 \mathrm{a}, 21)$. The partisan divide was more pronounced on other matters that may have a bearing on the likelihood of deference to foreign governance authority. For example, Republicans were less likely than Democrats to agree that "[t]he U.S. should mind its own business internationally and let other countries get along the best they can on their own" (2005b,42). In addition, Republicans were less likely than Democrats to have confidence in diplomacy $(2005 \mathrm{a}, 21)$ and less likely than Democrats to agree that the U.S. "should cooperate fully with the United Nations" (2005b, 42) - attitudes which seem consistent with less willingness on the part of Republicans to defer to foreign governance authority.

${ }^{167}$ Alternatively, one might hypothesize that Democrats are more pro-plaintiff than Republicans, leading Democrats to grant forum non conveniens motions less frequently.

168 (Epstein and Knight 1998, 12; George and Epstein 1992, 325). For example, Congress can propose constitutional amendments or pass legislation overriding court decisions. It also can use judicial salaries, impeachment, or legislative limits on jurisdiction to "punish" justices for their decisions - and although this rarely occurs, the possibility of such measures gives justices an incentive to consider the policy preferences of the other branches 
Thus, the strategic model suggests that Congress and the president affect judicial decisionmaking and that "the direction of their influence reflects their partisan composition."169 The implication is that U.S. district court judges should be less likely to defer to foreign governance authority (including deference to foreign adjudicative authority on forum non conveniens grounds) when the political environment is Republican than when it is Democratic. ${ }^{170}$

- Realist Theory Hypothesis (H3): The greater the power of the state in which the alternative foreign court is located, the more likely a judge is to grant a forum non conveniens motion. Realist theories of international relations reinforce the attitudinal and strategic models' emphasis on the political determinants of transnational judicial governance, but with a focus on power rather than ideology. ${ }^{171}$ Because realist theory generally treats states as unitary actors, it is not clear from a realist perspective how national power should affect judicial decisionmaking. As a general matter, however, one might expect the likelihood of deference by one political actor to another (including deference to foreign adjudicative authority on forum non conveniens grounds) to be greater when the second is more powerful than the first. ${ }^{172}$

- Domestic Bias Hypothesis (H4): A judge is more likely to grant a forum non conveniens motion if there is a domestic defendant and less likely to do so if there is a domestic plaintiff. Nationality is another political factor that may influence transnational judicial governance: domestic courts may be biased in favor of their own nationals. ${ }^{173}$ Because a forum non conveniens motion is an attempt by the defendant to thwart the plaintiff's choice of forum, one would expect the presence of a U.S.

(Epstein and Knight 1998, 141-143). In addition, "government actors can refuse, implicitly or explicitly, to implement particular constitutional decisions, thereby decreasing the Court's ability to create efficacious policy" (Epstein and Knight 1998, 144).

${ }_{169}$ (George and Epstein 1992, 325).

${ }^{170}$ I coded the political environment as Republican if the president and at least one house of Congress were Republican, and as not Republican if the president was Democratic or both houses of Congress were Democratic. This approach is based on George and Epstein's $(1992,328)$ method of measuring the political environment, although I use a dummy variable rather than their three-level measure to ensure adequate cell size for the logit analysis. For simplification and to account for lame-duck status, I did not account for January when coding presidential transition years. For the Senate, I coded 2001 and 2002 as Democratic, because Democrats were in the majority for 8 of 12 months in 2001 and 11 of 12 months in 2002.

${ }^{171}$ See Morgenthau $(1978,5)$ ("statesmen think and act in terms of interest defined as power"); Waltz (1979, 97-98) (the distribution of power among states is a fundamental structural variable affecting state behavior); and Mearsheimer $(2001,2)$ ("[ $\mathrm{t}]$ he overriding goal of each state is to maximize its share of world power").

${ }^{172}$ As Alter $(2001,40)$ notes, some scholars of European integration argue that the national interest is the primary determinant of judicial decisionmaking. If this is true, then to the extent power defines national interests, it also should influence the decisions of courts. For the realist theory hypothesis (H3), I used the foreign state's annual gross domestic product ("Foreign State's GDP") and its total annual military spending ("Foreign State's Military Spending"). This approach follows Guzman and Simmons (2005). I use data for the year 2000 and apply a natural logarithmic transformation to improve symmetry. The data source is the World Bank's World Development Indicators, available at http://devdata.worldbank.org/data-query/. I only report results using Foreign State's GDP because Foreign State's Military Spending was not statistically significant in any of my tests, and it has more missing data than Foreign State's GDP.

${ }^{173}$ (Bhattacharya, Galpin and Haslem 2006; Moore 2003). However, empirical support for this proposition is mixed. While Bhattacharya, Galpin and Haslem (2006) and Moore (2003) find that pro-American bias exists, Clermont and Eisenberg (1996 and 2006) conclude that foreign parties actually fare better than their U.S. counterparts in U.S. federal courts. 
plaintiff to decrease the likelihood of dismissal and the presence of a U.S. defendant to increase the likelihood of dismissal.

- Liberal Theory Hypothesis (H5): A judge in a liberal democracy is more likely to grant a forum non conveniens motion when the state in which the alternative foreign court is located also is a liberal democracy. Beyond ideology, power and nationality, a fifth potential political factor is regime type. Anne-Marie Slaughter argues that there is an emerging global community of courts operating according to principles of "judicial comity," including the principle that "courts in different nations are entitled to their fair share of disputes — both as coequals in the global task of judging and as the instruments of a strong 'local interest in having localized controversies decided at home." "174 In earlier versions of her liberal theory of international law, however, she characterized this community of judges not as truly global, but rather as a more limited "zone of law" populated by liberal states. ${ }^{175}$ In other words, "the courts of liberal states handle cases involving other liberal states differently from the way they handle cases involving nonliberal states." 176 This implies that domestic courts in liberal democracies may be more likely to defer to the governance authority of a foreign state (including deference to foreign adjudicative authority on forum non conveniens grounds) when that foreign state also is a liberal democracy. ${ }^{177}$

\section{Rule of Law Factors Influencing Transnational Judicial Governance. An alternative} conception is that transnational judicial governance is characterized not primarily by politics, but by the rule of law, as the following hypotheses suggest:

- Legal Model Hypothesis (H6): A judge is more likely grant a forum non conveniens motion when there is not a U.S. plaintiff than when there is, but the nationality of the defendant should not matter. According to the legal model of judicial decisionmaking, court decisions are based on the application of legal doctrine to the

\footnotetext{
${ }^{174}$ Slaughter, New World Order, supra note _, at 87 (citing Gilbert, 330 U.S. at 509).

${ }^{175}$ Anne-Marie Burley, Law among Liberal States: Liberal Internationalism and the Act of State Doctrine, 92 Colum. L. Rev. 1907, 1917 (1992).

176 (Burley 1992, 1917). She specifically suggests that these differences should be apparent in forum non conveniens decisionmaking (Slaughter Burley 1993, 232), which is the doctrine I explore in the empirical section of this paper.

${ }^{177}$ (Burley 1992, 1923) Alvarez (2001, 214-220) disagrees with Slaughter's theory, questioning the tenability of the liberal-illiberal distinction and arguing that the theory simply is not descriptively accurate: the courts of liberal democracies are not necessarily more deferential to the courts of other liberal democracies. To test the liberal theory hypothesis (H5), I used the variable "Liberal Democracy," which indicates whether the foreign state was rated "Free" by the Freedom House Freedom in the World Survey for the year prior to the court's decision (0 if no, 1 if yes). Although these ratings generally are stable over time during the period covered by my dataset, I use a one-year lag on the theory that a boundedly rational judge is unlikely to become immediately aware of even substantial changes in a foreign state's politics. For purposes of her theory, Slaughter defines "liberal" states as those "with juridical equality, constitutional protections of individual rights, representative republican governments, and market economies based on private property rights" (Burley 1992, 1909). The Freedom House rankings capture these characteristics quite nicely, by explicitly accounting for equal treatment under the law, protection of individual rights (including freedoms of assembly, open public discussion, and defendants' rights), representative government (including election of representatives through free and fair elections and other political rights), and private property rights (Freedom House 2006). The other leading measure of democracy, Polity IV, captures the concept of representative government well, but only indirectly captures the other elements of Slaughter's definition. Therefore, for testing Slaughter's liberal theory of international law, the Freedom House measure is more appropriate.
} 
facts of the case. ${ }^{178}$ Unlike the attitudinal and strategic models, which treat judges as policy maximizers, the legal model may be understood as treating judges as "law maximizers": decisions are made by applying legal rules to the specific facts of the case in order to reach the outcome that is most consistent with the applicable doctrine of law. ${ }^{179}$ Unfortunately, it is difficult to derive from the legal model a testable hypothesis about the impact of the forum non conveniens doctrine. While the doctrine identifies general factors for district courts to consider-including the availability and adequacy of the proposed foreign court and a variety of private and public interest factors-it does not explicitly identify the specific facts to used by the court in balancing these factors. ${ }^{180}$ However, one element of forum non conveniens analysis that provides a basis for deriving a statistical test of the legal model hypothesis is the nationality of the plaintiff. As the Supreme Court stated in Piper v. Reyno (1981), "a foreign plaintiff's choice [of a U.S. forum] deserves less deference" than that of a domestic plaintiff's choice. ${ }^{181}$ Thus, the citizenship of the plaintiff is a specific doctrinally-relevant fact which should, according to the legal model, influence the choice between domestic and foreign adjudicative authority in the forum non conveniens context. However, if there is a general bias in favor of U.S. parties that goes beyond that permitted by doctrine, as implied by the domestic bias hypothesis (H4), then both the plaintiff's and defendant's nationality should have an effect.

- Territorial Heuristic Hypothesis (H7): A judge is more likely to grant a forum non conveniens motion when the activity giving rise to the litigation occurred mostly or entirely outside U.S. territory. Finally, because U.S. district court judges face a daunting combination of limited decisionmaking resources and high decisionmaking demands, ${ }^{182}$ they may not be able to engage in the type of decisionmaking process

\footnotetext{
${ }^{178}$ As characterized by George and Epstein, the legal model posits that "legal doctrine, generated by past cases, is the primary determinant of extant case outcomes" $(1992,324)$, and, as described by Segal, Songer and Cameron, it holds that judges make decisions based on "the facts of the case in light of [the legal] text, intent, and precedent" $(1995,235)$.

${ }^{179}$ For example, Segal (1984) develops a legal model of U.S. Supreme Court decisionmaking in Fourth Amendment search and seizure cases by surveying the Court's search and seizure doctrine to identify a number of specific facts (such as whether the search was of the defendant's home, business, car or person) and subsidiary legal conclusions (such as whether there was probable cause for the search and whether the search was incident to a lawful arrest) that the doctrine identifies as relevant to a determination of whether a search or seizure is reasonable. Legal realists famously criticized this interpretation of judicial decisionmaking as "mechanical jurisprudence." [cites] However, as Segal clarifies, this type of legal model should not be expected to determine court decisions; but the identified factors "should strongly predispose the Court toward finding the search reasonable or unreasonable" $(1984,893)$ and, in his empirical tests, the model was able to predict accurately a substantial proportion of the Court's decisions. George and Epstein (1992) used the same approach to develop and empirically test a legal model of Supreme Court decisionmaking in death penalty cases.

${ }^{180}$ See Davies, supra note , at 316-364 (comprehensively surveying the elements of the forum non conveniens doctrine, noting the doctrine's failure to give courts factual guidance), David W. Robertson, The Federal Doctrine of Forum Non Conveniens: “An Object Lesson in Uncontrolled Discretion,” 29 Tex. Int'l L. J. 353 (1994) (title speaks for itself), and Allan R. Stein, Forum Non Conveniens and the Redundancy of Court-Access Doctrine, 133 U. Penn. L. Rev. 781 (1985) (criticizing the high degree of discretion that the doctrine vests in district courts). For a more in depth discussion of the difficulty of deriving a legal model for the forum non conveniens doctrine, see Whytock, Transnational Judicial Governance, supra note _, Appendix B.

181454 U.S. 235, 266.

${ }^{182}$ The workload of courts is heavy for all levels of the federal judiciary (Carp, Stidham, and Manning 2004, 52); but unlike the Supreme Court, district courts are unable to control their caseload. Since 1995 there have been approximately 400 to 500 pending cases per judge in the U.S. district courts each year. The data is from the Federal
} 
implied by the legal model, including thorough analysis of legally relevant facts and systematic application of complex legal principles to those facts. Forum non conveniens decisionmaking is likely to be particularly problematic in this respect, given that the doctrine calls on judges to consider "all [of the] relevant public and private interest factors" set forth in the Supreme Court's precedents, ${ }^{183}$ and the lack of specific guidance it offers on how to evaluate those factors. ${ }^{184}$ Rather, judges may behave more like boundedly rational actors, ${ }^{185}$ basing their decisions largely on decisionmaking shortcuts or "heuristics" that allow them to conserve decisionmaking resources while keeping error costs to a minimum. ${ }^{186}$ One likely heuristic is territoriality: the extent to which the transnational activity giving rise to the litigation occurred outside U.S. territory. This heuristic attribute reduces decisionmaking costs, because it is easier to evaluate than the elements enumerated by the Supreme Court in its forum non conveniens precedents. Yet it is not likely to entail excessive error costs, because territoriality is likely to be correlated with some of these elementssuch as ease of access to evidence and whether the controversy is considered

Court Management Statistics published by the Administrative Office of the U.S. Courts, available at $\mathrm{http} / / / \mathrm{www}$.uscourts.gov/fcmstat/index.html.Because judicial appointments have not kept pace with growing dockets, "federal judges, at both the trial and circuit court levels, are under severe resource and expertise constraints"; they face "an overwhelming caseload and limited time and resources with which to decide those cases" (Bainbridge and Gulati 2002, 86, 102). As a result, "a significant portion of [lower court] decision making must be done on the spur of the moment, without the luxury of lengthy reflection or discussion with staff or colleagues" (Carp, Stidham, and Manning 2004, 282).

${ }^{183}$ Reyno, 454 U.S. at 257. See also Davies, supra note _, at 351 (“" $[\mathrm{t}]$ he Reyno court implied that all public and private factors should be considered in all cases").

${ }^{184}$ Whytock, Transnational Judicial Governance, supra note _, at 16-17 and Appendix B.

${ }^{185}$ The neoclassical concept of rationality assumes that individuals maximize their utility by making the choice that yields the greatest expected utility, discounted by costs, based on a comprehensive analysis of available information - which, in the case of uncertainty or incomplete information, includes the estimation of a probability distribution associated with outcomes (Jones 1999, 299). In contrast, following Bainbridge and Gulati (2002) and Segal (1986), I assume that judges are boundedly rational decision makers: that is, they are goal-oriented, but due to their cognitive limitations - particularly their limited ability to gather and process information - they are unable to maximize in the neoclassical sense. Because boundedly rational actors cannot maximize, they satisfice: that is, the decisionmaking process is "usually terminated with the discovery of satisfactory, not optimal, courses of action" (Simon 1985, 295). Thus, whereas the legal model treats judges as law maximizers, the heuristics model understands them as "law satisficers."

${ }^{186}$ In the language of cognitive psychology, heuristics involve a process of "attribute substitution": "whenever the aspect of the judgmental object that one intends to judge (the target attribute) is less readily assessed than a related property that yields a plausible answer (the heuristic attribute)," individuals may substitute the former with the latter (Kahneman and Frederick 2005, 269). The relative accessibility of heuristics-in terms of lower information gathering or information processing demands - reduces decisionmaking costs, thus helping decision makers conserve decisionmaking resources. Bainbridge and Gulati (2002), Guthrie, Rachlinksi, and Wistrich (2001) and Segal (1986) have all found that judicial decisionmaking relies heavily on heuristics "to cut down on comprehensive decision making" (Segal 1986, 941), and this makes sense, especially at the district court level where, as discussed above, judges face a particularly acute combination of high decisionmaking demands and limited decisionmaking capacity. When an applicable legal doctrine specifies the factors for making a particular type of legal decision, these factors can be understood as the relevant target attributes. From this perspective, bounded rationality suggests that if assessing the doctrinally-specified target attributes requires too much information gathering or cognitive effort, judges will replace them with heuristic attributes that are conceptually related and provide plausible answers, but entail lower decision costs. In plain English, "difficult questions are often answered by substituting an answer to an easier one" (Kahneman and Frederick 2005, 269). More precisely for this study, judges may replace answers to difficult legal questions with answers to related but relatively simple questions. 
"local."187 It is important to emphasize that the use of heuristics does not imply that judges do not take the law seriously. To the contrary, in my conception judicial heuristics are instruments that allow judges to do the best they can to abide by the norm of good faith judging given the reality of high decisionmaking demands and limited decisionmaking resources. ${ }^{188}$ For this reason, the use of the territoriality heuristic in transnational judicial governance can help domestic courts foster transnational rule of law - not the ideal-type "law maximizing" rule of law implied by the legal model, but rather a more modest "law satisficing" rule of law.

Additional Factors. I control for two additional factors that may influence the choice between domestic and foreign governance authority in the forum non conveniens context. First, U.S. federal district judges may be less inclined to dismiss cases involving issues that they perceive as particularly salient, such as issues involving federal statutes. ${ }^{189}$ Second, caseload may have an influence on lower court judicial decisionmaking. In the case of forum non conveniens decisionmaking, the implication would be that busier U.S. district courts are more likely to dismiss litigation in favor of a foreign court because this allows them to reduce their caseload. ${ }^{190}$ In fact, by including "[a]dministrative difficulties" resulting from congestion in its list of public interest factors, the Supreme Court in Gilbert v. Gulf Oil (1947) can even be understood as acknowledging that the forum non conveniens doctrine may be used as a caseload management tool.

\footnotetext{
${ }^{187}$ For a detailed explanation of the reasoning that motivates this hypothesis, see Whytock, Transnational Judicial Governance, supra note _, at 10-13. The main variable that I used to test the heuristics model hypothesis (H7) indicates whether the place of the activity giving rise to the transnational litigation was all or mostly outside U.S. territory ( 0 if no, 1 if yes). I coded the variable based on two factors, the place of the conduct of the defendant complained of by the plaintiff, and the place of the plaintiff's alleged injury, each as stated in the court's opinion. I coded the place variable as "yes" if both the place of conduct and the place of injury were entirely foreign, if the place of conduct was entirely foreign and the place of injury mixed, or if the place of injury was entirely foreign and the place of conduct mixed. When the place of conduct and place of injury were both mixed or all or mostly inside U.S. territory, I coded the place variable as "no," because under these circumstances the territoriality heuristic is not expected to point toward dismissing the case in favor of a foreign court.

${ }^{188}$ Thus, to Gillman's description of the norm of good faith judging as "a sense of obligation to make the best decision possible in light of one's general training and sense of professional obligation" $(2001,486)$, I would add "and in light of one's highly limited decisionmaking resources." See also Barry Friedman, Taking Law Seriously, 4 Perspectives on Politics 261, 265-270 (2006) (discussing legal norms).

${ }^{189}$ See (Hettinger, Lindquist, and Martinek 2004; Unah and Hancock 2006) (identifying case salience as a factor influencing judicial decisionmaking). As Hettinger, Lindquist and Martinek $(2004,130)$ argue in their study of dissenting behavior by appellate court judges, "the more salient a case is, the more likely it is to have policy consequences and, hence, the more likely it is to stimulate judges to devote the necessary effort to write a dissenting opinion." This reasoning implies that judges also should be less likely to grant motions to dismiss on forum non conveniens grounds in cases that raise particularly salient legal issues.

${ }^{190}$ See (Hettinger, Lindquist, and Martinek 2004, 134) (noting, however, that the empirical evidence for this proposition is mixed). To control for caseload effects, I used the variable "Caseload," which measures the number of cases filed in each district in the year prior to the court's decision. I use the natural logarithm of the "weighted filings per judgeship" figure from the Federal Judicial Center's Federal Court Management Statistics, Judicial Caseload Profiles, available at http://www.uscourts.gov/fcmstat/index.html, in the year prior to the court's decision. I use a one-year lag on the theory that because of the duration of cases, the prior year's filings are likely to be a more accurate measure of the district's current workload. I applied the logarithmic transformation to increase symmetry.
} 


\section{Table 4. Logit Analysis: Factors Influencing Choice between Assertion of Domestic Adjudicative Authority and Deference to Foreign Adjudicative Authority (Forum Non Conveniens Motions)}

\begin{tabular}{|c|c|c|c|c|}
\hline Independent Variable & $\begin{array}{c}\text { Change in } \\
\text { Independent } \\
\text { Variable }\end{array}$ & $\begin{array}{c}\text { Estimated } \\
\text { Change in } \\
\text { Probability } \\
(\%)\end{array}$ & $\begin{array}{l}\text { Type I Error } \\
\text { Rate }(\%)\end{array}$ & $\begin{array}{c}95 \% \\
\text { Confidence } \\
\text { Interval }\end{array}$ \\
\hline Republican Judge (H1) & no $\rightarrow$ yes & -9.6 & 14.6 & $-23.1,3.0$ \\
\hline Republican Political Environment (H2) & no $\rightarrow$ yes & -14.1 & 10.8 & $-32.9,2.8$ \\
\hline Domestic Plaintiff $(\mathrm{H} 4, \mathrm{H} 6)$ & no $\rightarrow$ yes & $-20.5 * * *$ & .1 & $-35.9,-9.2$ \\
\hline Domestic Defendant (H4) & no $\rightarrow$ yes & -10.8 & 23.3 & $-28.5,5.4$ \\
\hline Foreign State's GDP (H3) & $\begin{array}{l}25^{\text {th }} \rightarrow 75^{\text {th }} \\
\text { percentile }\end{array}$ & 1.2 & 81.1 & $-9.7,12.0$ \\
\hline $\begin{array}{l}\text { Foreign State is Liberal Democracy } \\
\text { (H5) }\end{array}$ & no $\rightarrow$ yes & $32.2 * *$ & .2 & $10.3,51.5$ \\
\hline $\begin{array}{l}\text { Locus of Activity All or Mostly } \\
\text { Extraterritorial (H7) }\end{array}$ & no $\rightarrow$ yes & $42.1 * * *$ & $<.1$ & $25.1,56.4$ \\
\hline Federal Statute & no $\rightarrow$ yes & -10.0 & 26.8 & $-27.7,8.1$ \\
\hline Caseload & $\begin{array}{l}25^{\text {th }} \rightarrow 75^{\text {th }} \\
\text { percentile }\end{array}$ & .3 & 92.4 & $-9.3,9.5$ \\
\hline \multicolumn{5}{|l|}{$\begin{array}{l}\mathrm{N}=191 \\
\text { Prob. }>\text { LR Chi-squared }=0.000 \\
\text { Correctly Classified: } 72.8 \% \\
\text { Adjusted Count } \mathrm{R}^{2}: .435 \\
\text { Area under ROC Curve: } .8159\end{array}$} \\
\hline \multicolumn{5}{|c|}{$\begin{array}{l}\text { Notes: (1) I used the Clarify software program to simulate the change in the expected value of the dependent variable caused by } \\
\text { increasing each independent variable from } 0 \text { to } 1 \text { (in the case of dummy variables) and from the } 25 \text { th to the } 75 \text { th percentile (in the } \\
\text { case of continuous variables), setting each of the other variables at their mode (for dummy variables) or mean (for continuous } \\
\text { variables). Michael Tomz, Jason Wittenberg \& Gary King, CLARIFY: Software for Interpreting and Presenting Statistical Results } \\
\text { (2001). (2) *p }<0.05, * * p<0.01, * * * \text { p }<0.001 \text {. (3) The "correctly classified" figure indicates the proportion of outcomes that were } \\
\text { correctly classified by the model using a .5 probability cutoff to translate predicted probabilities into dichotomous predictions. } \\
\text { Lawrence C. Hamilton, Statistics with Stata } 270-271 \text { (2004). Thus, it indicates the proportion of outcomes for which the model } \\
\text { estimated at least a .5 probability of deference to foreign governance authority, and the court in fact deferred. (4) Adjusted count R2 } \\
\text { is the proportion of correct predictions beyond the number that would be correctly predicted simply by choosing the outcome with } \\
\text { the largest percentage of observed cases, using a .5 probability cutoff. J. Scott Long \& Jeremy Freese, Regression Models for } \\
\text { Categorical Dependent Variables Using Stata } 111-112 \text { (2d ed. 2006). (5) The ROC curve plots } 1 \text { minus the specificity (the false } \\
\text { positive rate) on the x-axis and sensitivity (the true positive rate) on the y-axis for each possible probability cutoff. The area under } \\
\text { the ROC curve is equal to the probability that a random decision granting a forum non conveniens motion has a higher value of the } \\
\text { dependent variable than a random decision denying a forum non conveniens motion. Douglas G. Altman \& J. Martin Bland, } \\
\text { Receiver Operating Characteristic Plots, } 188 \text { Brit. Med. J. } 188 \text { (1994). The larger the area under the curve, the more discriminating } \\
\text { the model. }\end{array}$} \\
\hline
\end{tabular}


Discussion of Results. The results in Table 4 above suggest that a combination of political and legal factors influence the choice between assertion of domestic governance authority and deference to foreign governance authority over transnational activity in the forum non conveniens context. Regarding the hypothesized political factors, the results do not support the attitudinal model hypothesis ( $\mathrm{H} 1)$, the strategic model hypothesis (H2), the domestic party bias hypothesis (H3), or the realist theory hypothesis (H4). Except for Domestic Defendant, which has a negative sign whereas the domestic party bias hypothesis suggests that it should have a positive effect on the probability of forum non conveniens dismissal, the estimated effects of the relevant variables have their expected signs (a negative effect for Republican Judge and Republican Political Environment, and a positive effect for Foreign State's GDP). However, none of these effects are statistically significant at conventional levels. That is, there is more than a 5 percent probability of what statisticians call "type I error"- the error of rejecting the "null" hypothesis that there is no relationship between two variables when, in fact, the null hypothesis is true and the apparent relationship is merely the result of chance. For some variables, the likelihood of type I error is substantially higher. ${ }^{191}$

In contrast, the results do furnish support for the liberal theory hypothesis (H5): U.S. district courts appear to be more likely to defer to foreign adjudicative authority when the foreign state is a liberal democracy than when it is not. As Table 4 shows, the likelihood of a forum non conveniens dismissal is an estimated 32.2 percent higher when the foreign state is a liberal democracy than when it is not, with 95 percent certainty that the actual difference in the full population of published U.S. district court forum non conveniens decisions is between 10.3 and 51.5 percent. The type I error rate indicates that the probability that the apparent relationship between liberal democracy and deference to foreign adjudicative authority is due to chance is very low (less than 1 percent).

Regarding the hypothesized rule-of-law factors, the results provide some support for the legal model hypothesis (H6). The Supreme Court in Reyno made it clear that less deference should be given to a foreign plaintiff's choice of a U.S. forum-but as Martin Davies asks in his comprehensive review of the forum non conveniens doctrine: "Less than what?"192 Although the doctrine does not provide the answer, forum non conveniens in action, according to the results, shows that U.S. district court judges are an estimated 20.5 percent less likely to dismiss (thus deferring to foreign adjudicative authority) when there is a domestic plaintiff than otherwise, with a 95 percent certainty that the actual difference in the full population of published U.S. district court forum non conveniens decisions is between -35.9 and -9.2 percent. The type I error rate indicates that the probability that the apparent relationship between the plaintiff's nationality and deference to foreign adjudicative authority is due to chance is less than one-tenth of one percent. As noted earlier in my discussion of descriptive inferences about dismissal rates with domestic and foreign plaintiffs, ${ }^{193}$ from an internal rule of law perspective, the fact that the

\footnotetext{
${ }^{191}$ As with any statistical tests, the results of my test do not "disprove" these hypotheses (or "prove" others). Rather, insofar as these methods are probabilistic, they estimate the likelihood of particular relationships and the degree of certainty one can have that the actual magnitude of a particular effect is within a certain range (for example, the 95 percent confidence intervals indicate that there is 95 percent certainty that an actual effect is between the two values listed). In short, statistical findings are evidence, not proof.

${ }^{192}$ Davies, supra note , at 313.

${ }^{193}$ See supra, notes __-, and accompanying text.
} 
plaintiff's nationality has a causal effect (if not necessarily the full magnitude of this effect) is consistent with the impartial application of the forum non conveniens doctrine as stated by the Supreme Court. But from an external perspective, this effect clearly is not so easily reconciled with the value of impartiality.

The most important effect appears to be territoriality. Consistent with the territoriality heuristic hypothesis (H7), U.S. district court judges are an estimated 42.1 percent more likely to defer to foreign adjudicative authority when the transnational activity giving rise to the litigation occurred all or mostly outside U.S. territory, with a 95 percent certainty that the actual difference in the full population is between 25.1 and 56.4 percent. Not only is this substantively a very important effect; the probability of type I error is less than one-tenth of one percent. However, in the study of judicial decisionmaking "a particular pattern of behavior usually is susceptible to more than one reasonable interpretation."194 This problem cannot be taken lightly in the study of judicial heuristics. As discussed above, for a particular heuristic to be a plausible explanation for judicial decisionmaking, it must tend not to result in decisions that clearly are legally erroneous, which means that it must have some relationship to doctrinally-specified decisionmaking factors. This creates a threat to inference, because a pattern of decisionmaking that appears driven by such a heuristic may in fact partly reflect legal analysis of those factors rather than the use of decisionmaking shortcuts.

To mitigate this threat and to discriminate more effectively between law and heuristics, I conducted a qualitative analysis of each of the 210 judicial opinions in my dataset using the method of structured, focused comparison. ${ }^{195}$ The comparison focuses on the judge's legal analysis of the forum non conveniens issue as set forth in the opinion, with the goal of evaluating the extent to which the judge actually analyzed the factors specified in the U.S. Supreme Court's statements of the forum non conveniens doctrine. After Reyno, judges are to consider not only "all [of the] relevant public and private interest factors," but also the appropriate level of deference owed to the plaintiff's choice of forum and the availability and adequacy of the proposed foreign court. ${ }^{196}$ Thus, an observable implication of the legal model is that most of these factors will be analyzed, whereas an observable implication of the heuristics model is that at least some of them will not. ${ }^{197}$ To structure the comparison, I divided the forum non conveniens doctrine, as set forth by the Supreme Court in Gilbert and Reyno, into eleven distinct elements, and systematically applied them by giving each case one point for each element of doctrine analyzed in the opinion. ${ }^{198}$

\footnotetext{
${ }^{194}$ Lawrence Baum, What Judges Want: Judges’ Goals and Judicial Behavior, 47 Pol. Res. Q. 749, 762 (1994)

195 Alexander L. George \& Andrew Bennett, Case Studies and Theory Development in the Social Sciences chap. 3 (2005).

${ }^{196}$ Reyno, 454 U.S. at 257. See also Davies, supra note _, at 351 ("[t]he Reyno court implied that all public and private factors should be considered in all cases").

${ }^{197}$ As Segal $(1984,894)$ and Spaeth $(1995,296)$ note, the presence of analysis in a judicial opinion does not necessarily mean that it was an a priori basis for the judge's decision rather than a post hoc justification for it. Thus, there is some risk that my method overestimates the impact of legal analysis.

${ }^{198}$ See Whytock, Transnational Judicial Governance, supra note _, at 25-26 and Appendix B for details on this methodology. Legal analysis is the application of applicable legal principles to the facts in order to generate a legal conclusion. Therefore, I gave points for combined statements of law and fact, but not for mere recitation of legal principles or summary legal conclusions not explicitly based on some fact.
} 


\begin{tabular}{|lcccc|}
\hline \multicolumn{5}{l}{ Table 5. Elements of Forum Non Conveniens Analysis Included in Judges' Opinions } \\
\hline $\begin{array}{l}\text { Elements of Forum Non } \\
\text { Conveniens Analysis }\end{array}$ & $\begin{array}{c}\text { Points } \\
\text { Possible }\end{array}$ & Mean & Std. Error & $\begin{array}{c}95 \% \text { Confidence } \\
\text { Interval }\end{array}$ \\
\hline $\begin{array}{l}\text { Level of Deference } \\
\text { Alternative Forum }\end{array}$ & 1 & .467 & .034 & $.400, .534$ \\
Private Interest Factors & 1 & .552 & .034 & $.485, .618$ \\
Public Interest Factors & 4 & 2.152 & .081 & $1.993,2.311$ \\
\hline Total & 5 & 2.110 & .108 & $1.900,2.323$ \\
\hline
\end{tabular}

Table 5 above presents the results of the qualitative analysis. Overall, U.S. district court judges include in their opinions an average of only five of eleven elements of forum non conveniens analysis. This represents an estimated average of 48 percent of the elements, with a 95 percent level of confidence that the actual average is between 44 and 52 percent. The result is consistent across the four main parts of the forum non conveniens doctrine, with only 47 percent of cases addressing the level of deference owed to the plaintiff's choice of forum based on the plaintiff's citizenship, and only 55 percent including an analysis of the proposed alternative forum. ${ }^{199}$ Similarly, judges analyzed an average of only 2.15 private interest elements out of four and only 2.11 public interest elements out of five. This evidence is what the heuristics model would predict, but it is difficult to reconcile with the legal model. Therefore, although the statistical analysis above suggests that at least one legal factor-whether the plaintiff is domestic - has an important influence on forum non conveniens decisionmaking, I tentatively conclude that the heuristics model more accurately describes the causal mechanism that underlies the choice between domestic and foreign adjudicative authority in forum non conveniens decisionmaking. If this is correct, then to the extent U.S. district courts are fostering transnational rule of law, it is not an ideal-type "law maximizing" rule of law as contemplated by the legal model. Rather, it is a more modest "law satisficing" rule of law which, given the high decisionmaking demands placed on U.S. district court judges, their limited decisionmaking resources, and the nature of the forum non conveniens doctrine itself, may presently be all that we can reasonably hope for.

Predictability. In his dissent in Gilbert, Justice Black strongly criticized the Supreme Court's endorsement of the forum non conveniens doctrine, arguing that " $[\mathrm{t}]$ he broad and indefinite discretion left to federal courts to decide the question of convenience from the welter of factors which are relevant to such a judgment will inevitably produce a complex of close and indistinguishable decisions from which accurate prediction of the proper forum will become difficult, if not impossible."200 More recently, Justice Scalia argued that "[ $t]$ he discretionary nature of the doctrine, combined with the multifariousness of the factors relevant to its

\footnotetext{
${ }^{199}$ Note that in some cases the judge may omit analysis of the alternative forum because the plaintiff does not challenge its availability and adequacy.

${ }^{200}$ Gilbert, 330 U.S. at 516.
} 
application, make uniformity and predictability of outcome almost impossible." 201 And if there is one thing that scholars of forum non conveniens agree about, it is that the doctrine produces unpredictable results. ${ }^{202}$

In principle, however, forum non conveniens decisionmaking is not unpredictable. As Table 4 above indicates, when the political and legal factors suggested by the seven hypotheses discussed above are taken together, they are able to correctly classify more than 70 percent of published U.S. district court forum non conveniens decisions. The "adjusted count R-squared" statistic indicates that these factors correctly predict these decisions 43.5 percent more accurately than simply predicting that the motion will be denied, which is the most frequently observed outcome. $^{203}$ Even the territorial heuristic by itself - whether the transnational activity giving rise to the litigation occurred all or mostly outside U.S. territory-is able to predict 70 percent of the decisions, which is not bad for a rule of thumb. One would be hard-pressed to find many examples of legal decisionmaking that can be predicted with much more accuracy than this given the limited determinacy of legal texts and the disincentive to sue that becomes increasingly strong as legal outcomes become increasingly certain. ${ }^{204}$

But the rule of law demands more than this. The factors influencing judicial decisionmaking, including forum non conveniens decisionmaking, should be discernable in doctrine, not only in the results of statistical analysis. Yet the doctrine does not suggest that the foreign state's status as a liberal democracy is a relevant factor, and while several factors that are doctrinally relevant may in some cases be correlated with the location of the transnational activity giving rise to litigation, the doctrine does not explicitly identify territoriality as a relevant factor. This is a problem for at least two reasons. First, inclusion in legal doctrine of the actual factors influencing court decisions is a functional requirement for realizing the value of predictability, since transnational actors and their attorneys obviously are far more likely to have knowledge of U.S. legal doctrine than patterns and determinants of U.S. district court decisionmaking such as those considered in this paper-even if Holmes' "bad man" would like to find an attorney with sound knowledge of the latter. ${ }^{205}$ Second, the rule-of-law value of impartiality insists on not simply equal treatment by agents of the state, but equal treatment in accordance with recognized legal rules, the status of which is enjoyed by legislation and

\footnotetext{
${ }^{201}$ American Dredging Company v. Miller, 510 U.S. 443, 455 (1994).

202 David W. Robertson, The Federal Doctrine of Forum Non Conveniens: “An Object Lesson in Uncontrolled Discretion," 29 Tex. Int'1 L. J. 353, 358-359 (1994). See also [cites]

${ }^{203}$ Long and Freese 2006, 111-112. Forum non conveniens motions are denied in an estimated rate of 53 percent in published U.S. district court decisions, with 95 percent certainty that the actual rate is between 40.5 and 53.9 percent.

${ }^{204}$ Early arguments about the decision to sue rather than settle used this logic to conclude that litigation success rates for plaintiffs generally will tend toward 50 percent, for higher success rates would induce defendants to settle rather than litigate, and lower success rates would induce plaintiffs to settle rather than litigate. George L. Priest \& Benjamin Klein, The Selection of Disputes for Litigation, 13 J. of Leg. Stud. 1 (1984). Subsequent theoretical and empirical research has challenged the 50 percent hypothesis, identifying a variety of factors-including the parties' stakes, misperception, and asymmetric information, but reinforced that conclusion that "disputes and cases that clearly favor either the plaintiff or the defendant tend to settle readily, because both sides can save costs by settling in light of their knowledge of the applicable law and all other aspects of the case." Kevin M. Clermont \& Theodore Eisenberg, Litigation Realities, 88 Cornell L. Rev. 119 138-140 (2002). 205 [cite]
} 
Supreme Court precedents, but not naked decisionmaking outcomes. ${ }^{206}$ For these reasons, although my statistical analysis suggests that forum non conveniens decisions are, taken together, neither arbitrary nor indistinguishable, this is at best only partially good news for the ability of domestic law and domestic courts to foster transnational rule of law.

\section{CONCLUSION}

Domestic courts routinely make decisions that allocate values among transnational actors, and these decisions have broad implications for transnational activity, making transnational judicial governance a distinct and important object of study. The goal of the governanceoriented approach to transnational law is to improve our knowledge of transnational judicial governance, and to use that knowledge as an empirical foundation for normative analysis.

In this paper, I applied the governance-oriented approach to the allocation of adjudicative authority by U.S. district courts under the doctrine of forum non conveniens. From a rule of law perspective, the results are mixed. On the one hand, there is evidence, albeit inconclusive, that dismissals may be more common than contemplated by Supreme Court precedent. Forum non conveniens in action exhibits a strong bias against foreign plaintiffs, an outcome that might be justified from an internal rule of law perspective since the forum non conveniens doctrine condones it, but one that is not easily squared with the value of impartiality from an external rule of law perspective. U.S. district courts routinely dismiss transnational litigation in favor of foreign courts without engaging in the analysis necessary to meaningfully assess their adequacy. And decisions do not appear to be based on the systematic application of the factors specified by doctrine.

On the other hand, the evidence clearly indicates that U.S. district courts are willing to defer, and in fact frequently do defer, to foreign governance authority - which is a necessary condition for the emergence of a global community of courts on the basis of judicial comity, and arguably a necessary condition for any well-functioning system of transnational judicial governance. Cases rarely are dismissed in favor of foreign courts in states with below-average rule of law ratings - a desirable outcome, even if U.S. district courts do not necessarily deserve the credit. Political factors do not appear to be important drivers of the allocation of adjudicative authority, with the interesting exception of the foreign state's regime type. And because they face a difficult combination of high decisionmaking demands and limited resources, to the extent U.S. district courts actually use the territoriality heuristic as a decisionmaking shortcut, doing so can be understood not as an abdication of the law, but as an effective tool for fostering transnational rule of law to the greatest extent practicable under the circumstances that confront them.

What do these findings about forum non conveniens in action tell us about transnational judicial governance? One must generalize with caution. Judicial allocation of adjudicative authority among states in forum non conveniens decisionmaking may differ from the allocation of other values by domestic courts in other legal settings. Nevertheless, the foregoing analysis

\footnotetext{
${ }^{206}$ See the discussion of rule of law values, supra notes _- and accompanying text. For an excellent discussion of the importance of distinguishing legal precedent from legal outcomes, and an argument that the failure to do so has led some scholars of judicial politics astray, see Friedman, supra note _, at 265-267.
} 
may offer some clues about the ability of domestic courts to foster the transnational rule of law, which I will state as a series of four tentative propositions. First, the ability of domestic courts to foster transnational rule of law largely depends on transnational legal doctrine. Without relatively clear and simple legal rules to follow, there is only so much that judges can do to enhance the kind of predictability demanded by the rule of law, namely predictability based on recognized legal rules rather than naked judicial practice. Second, both legal and non-legal factors influence the way that domestic courts behave as global governors, but transnational judicial governance is not political in a partisan sense. Third, one might argue that transnational judicial governance is, for certain realms of transnational activity, preferable to alternative forms of governance such as international institutions or private governance. But even if it is the best available solution - which, of course, is debatable - it also is less than ideal from a rule of law perspective, and inevitably so under present conditions. Finally, these conditions could be improved. Imbalances between decisionmaking demands and decisionmaking resources are not intrinsic to domestic courts as institutions. Nor are vague and complex legal doctrines like forum non conveniens inevitable. The constraints of judges' bounded rationality could be mitigated (although never eliminated) by increasing judicial resources or by simplifying legal doctrine, thereby enhancing the ability of domestic courts to foster transnational rule of law. Further governance-oriented analysis of transnational law may be able to shed light on the validity of these propositions and improve our overall understanding of transnational judicial governance. 